\title{
SAND AND SILTY-SAND SOIL STABILIZATION USING BACTERIAL ENZYME INDUCED CALCITE PRECIPITATION (BEICP)
}

\begin{tabular}{|c|c|}
\hline Journal: & Canadian Geotechnical Journal \\
\hline Manuscript ID & cgj-2018-0191.R1 \\
\hline Manuscript Type: & Article \\
\hline $\begin{array}{r}\text { Date Submitted by the } \\
\text { Author: }\end{array}$ & 12-Jul-2018 \\
\hline Complete List of Authors: & $\begin{array}{l}\text { Hoang, Tung; Iowa State University, Department of Civil, } \\
\text { Construction, and Environmental Engineering } \\
\text { Alleman, James; Iowa State University, Department of Civil, } \\
\text { Construction, and Environmental Engineering } \\
\text { Cetin, Bora; Iowa State University, Department of Civil, } \\
\text { Construction, and Environmental Engineering } \\
\text { Ikuma, Kaoru; Iowa State University, Department of Civil, } \\
\text { Construction, and Environmental Engineering } \\
\text { Choi, Sun-Gyu; Korea Advanced Institute of Science and } \\
\text { Technology }\end{array}$ \\
\hline Keyword: & Shear Strength, Biostabilization, Enzyme, Bacteria \\
\hline $\begin{array}{r}\text { Is the invited manuscript } \\
\text { for consideration in a } \\
\text { Special Issue? : }\end{array}$ & Not applicable (regular submission) \\
\hline
\end{tabular}




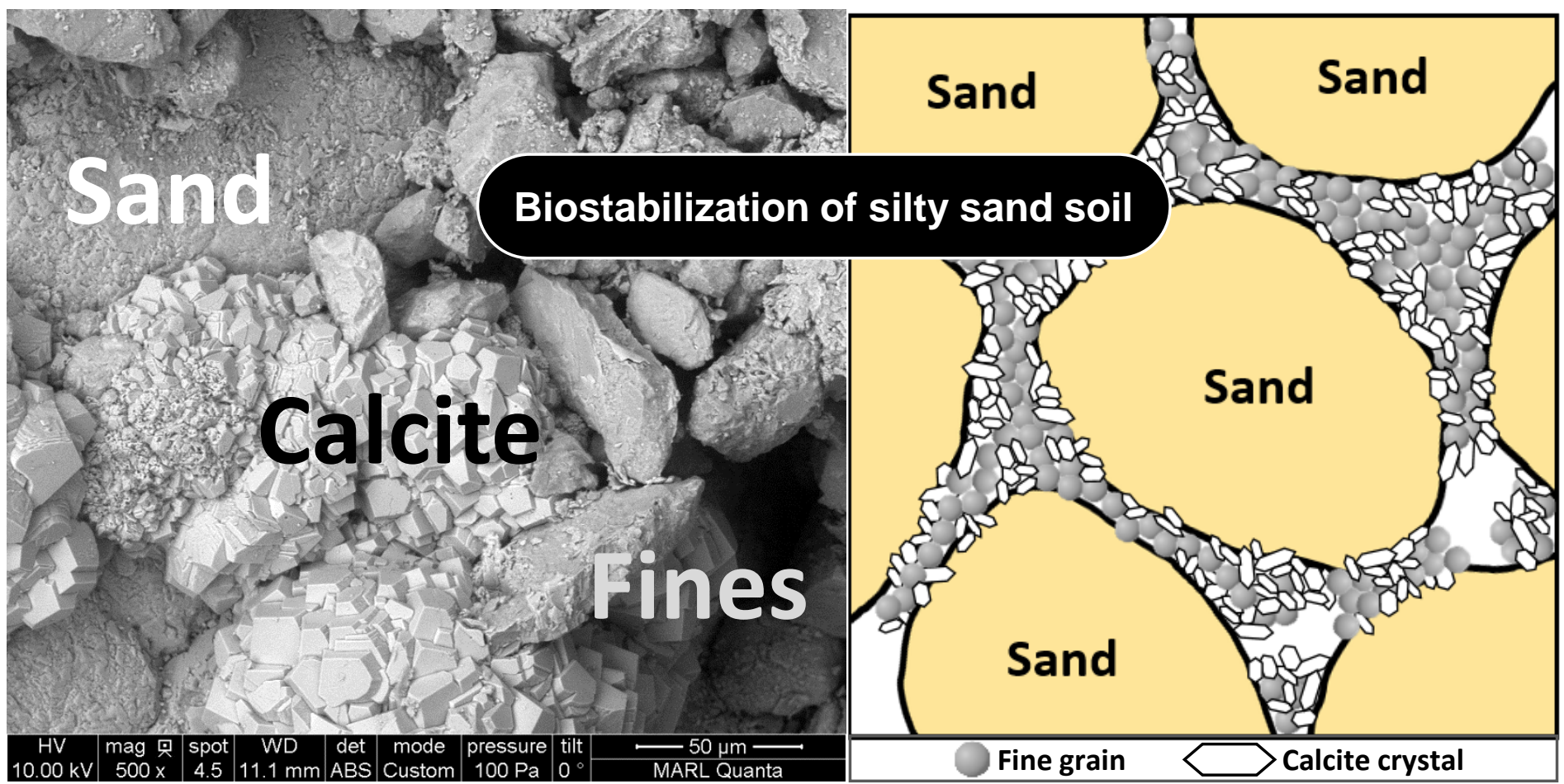




\title{
SAND AND SILTY-SAND SOIL STABILIZATION USING BACTERIAL ENZYME INDUCED CALCITE PRECIPITATION (BEICP)
}

Tung Hoang ${ }^{1}$, James Alleman², Bora Cetin ${ }^{3}$, Kaoru Ikuma ${ }^{4}$, and Sun-Gyu Choi ${ }^{5}$

\begin{abstract}
This paper examines the bio-derived stabilization of sand-only or sand-plus-silt soils using an extracted bacterial enzyme application to achieve induced calcite precipitation (ICP). As compared to conventional microbial induced calcite precipitation (MICP) methods, which use intact bacterial cells, this strategy which uses free urease catalysts to secure bacterial enzyme induced calcite precipitation (BEICP) appears to offer an improved means of biostabilizing siltysand soils as compared to that of MICP processing. Several benefits may possibly be achieved with this BEICP approach, including bio-safety, environmental, and geotechnical improvements. Notably, the BEICP biostabilization results presented by this paper demonstrate: 1) higher rates of catalytic urease activity, 2) a wider range of application with sand-plus-silt soil applications bearing low plasticity properties, and 3) the ability to retain higher levels of soil permeability after BEICP processing. Comparative BEICP versus MICP results for sand-only systems are presented, along with BEICP-based results for stabilized soil mixtures at 90-10 and 80-20
\end{abstract}

${ }^{1} \mathrm{PhD}$ candidate, Department of Civil, Construction, and Environmental Engineering, Iowa State University, Ames, Iowa, 50014 \& The University of Danang - University of Science and Technology, Danang, Vietnam, tphoang@iastate.edu

${ }^{2}$ Professor, Department of Civil, Construction, and Environmental Engineering, Iowa State University, Ames, Iowa, 50014,jea@iastate.edu

${ }^{3}$ Assistant Professor, Department of Civil, Construction, and Environmental Engineering, Iowa State University, Ames, Iowa, 50014, bcetin@iastate.edu

${ }^{4}$ Assistant Professor, Department of Civil, Construction, and Environmental Engineering, Iowa State University, Ames, Iowa, 50014,kikuma@iastate.edu

${ }^{5}$ Postdoctoral Researcher, Department of Civil and Environmental Engineering, Korea Advanced Institute of Science and Technology (KAIST), Daejeon, Korea, choisg@kaist.ac.kr 
percentile sand-silt ratios. This BEICP method's ability to obtain unconfined compressive strength (UCS) results in excess of 1,000 $\mathrm{kPa}$ with sand-plus-silt soil mixtures is particularly noteworthy.

Keywords: Shear Strength, Biostabilization, Enzyme, Bacteria

\section{INTRODUCTION}

This paper's coverage of a bacterial enzyme induced calcite precipitation (BEICP) procedure represents yet another iterative refinement of the overall concept of bio-inspired soil stabilization, which has evolved over the past several decades. The original, first-generation concept of using calcite precipitation by live, urease-active bacteria, albeit for improved oil recovery, dates back to the original work by Ferris and Stehmeier (1991), Ferris et al. (1991), and Kantzas et al. (1992). In turn, after shifting this concept's focus to soil biostabilization, several hundred papers have now been published in relation to application strategies and performance outcomes when using microbial induced calcite precipitation (MICP). The MICP mechanism is a calcium carbonate precipitation process derived from hydrolysis of urea following supplying calcium source as a result in a pH increase through the production of ammonia and an increase in $\mathrm{CaCO}_{3}$ deposition and accumulation (van Paassen 2009; Whiffin 2004). The urea hydrolysis is carried out through urease enzyme generated from ureolytic bacteria. The bacterial cells are also nucleation sites on which calcite crystallization takes place to bind sand grains. These research findings, though, have revealed a couple of important application concerns. One notable issue raised by Kavazanjian and Hamdan (2015) involved the physical migration of MICP's ureasebearing microbes, which was thought to be limited to soils with pore spaces larger than that of 
medium to fine sands. In turn, at that point in time (circa 2015) MICP did not appear to be well suited to soil systems bearing finer-grained, higher plasticity soils which would then impede bacterial migration. The validity of this concern, though, is now unclear given that a limited number of more recently published papers have claimed successful MICP use with residual soil and silty sand soil (Lee et al. 2013; Soon et al. 2013, 2014; Oliveira et al. 2016; Jiang et al. 2017). A further complicating concern for MICP operations, though, involves the complex life cycle of these microbial cells when they are transferred from their original, synthetic growth culture media to a natural soil environment. This transition may impose negative impacts (e.g., lower metabolic rates during lag and adaptation phases), which in turn could retard the desired calcite precipitation. Even then, just growing and preserving the involved microorganisms under fieldlevel conditions would have its own set of complications. After two decades of active MICP research, therefore, it is noteworthy that relatively few large, meter-scale projects have yet been attempted within either lab or field studies using sand and natural soil systems (Burbank et al. 2011; Gomez et al. 2015; De Jong et al. 2009; Nassar et al. 2018; van Paassen et al. 2009, 2010a; van Paassen 2011; Phillips et al. 2016; van der Star et al. 2011).

Prompted by these issues, the notion of using free enzyme induced calcite precipitation (EICP) was then launched in the early 2000's. Bang et al. (2001) triggered this new line of thinking, where a commercially-purchased urease was used to secure EICP-based metabolism for crack repair with concrete materials. The EICP treatment method employs purified urease enzyme instead of urease producing bacteria as the ureolytic agent. The purified enzyme is extracted from plant sources, mainly from jack bean (Canavalia ensiformis). As such, the advantages of free enzyme biostabilization processing was conceptually recognized at a point many years 
before the concept of using EICP for soil stabilization had even been conceived. For example, Nemati and Voordouw (2003) studied the direct application of urease to reduce the permeability of porous media, and Nemati et al. (2005) stated that the quantity of calcium carbonate produced by urease was almost three times higher than had been measured with MICP treatment.

At the present time, therefore, approximately twenty-five free-urease EICP-related papers have been published within civil and environmental engineering venues. Table 1 summarizes these publications relative to their native free urease agent, enzyme source options, and intended application goals per each publication.

Furthermore, two related patents have been recorded for this approach, filed by Park et al. (2011) and Kavazanjian and Hamdan (2013). Several enzyme sources could have been used for the extracted free-urease agents applied during these prior EICP studies, including that of plant, bacterial, and even commercial sources. To date, though, all of the aforementioned EICP-related research findings have used either plant or commercial urease applications, as opposed to this paper's focus on bacterial-derived urease.

The more recent EICP papers (using plant and commercial enzyme sources) have also largely focused on sand-based soil applications, with limited consideration of more complex soil mixtures with higher plasticity. Five of these papers, though, did study varying sand, silt, clay, and/or dust mixtures (Bang et al. 2009; Kavazanjian and Hamdan 2015; Oliveira et al. 2016; Hamdan and Kavazanjian 2016; Kavazanjian et al. 2017), although with varying degrees of success. For example, Oliveira et al. (2016) reported relatively low unconfined strength results 
(i.e., with a maximal $250 \mathrm{kPa}$ UCS strength outcome) when treating a combined sand, silt, and clay soil using EICP processing.

This current paper consequently offers a set of new perspectives on the process and performance of EICP biostabilization, and uniquely that of the BEICP methodology, which were premised on the following two initial hypotheses:

(1) that the involved bacterial-derived urease enzymes could rapidly be grown and successfully extracted using sonication for subsequent BEICP use rather than relying on expensive commercial, or slower growing plant-based, enzymes sources, and

(2) that EICP-based biocementation of both sand and sand-silt soils could be achieved using a BEICP procedure which was uniquely different from the previously published MICP and EICP methods and outcomes.

This research effort subsequently started with the development of a sonication technique to lyse viable cells of Sporosarcina pasteurii bacteria in order to release their intracellular urease materials. This extracted enzyme was then used to treat a group of test columns bearing different percentages of natural fine-grained soil fractions by weight.

This paper investigated the applicability of BEICP processing, and notably that of using bacterial-derived urease enzymes, to stabilize both non-plastic, sand-only and low plasticity, silty-sand soil materials. Performance assessment included unconfined compressive strength measurements to quantify product soil stability, along with percentile calcium carbonate deposition levels plus product permeability. These results were correlated with three varied 
BEICP treatment regimes, including 8-, 12-, and 16-cycle sequential processing steps by which the operative free bacterial enzyme plus complementary urea and calcium chloride chemicals were applied. Triplicate testing was also conducted in each case to ensure valid performance outcomes.

\section{METHODS and MATERIALS}

\section{Bio-preparation procedures}

\section{Biomass culturing}

This project's commercial bacterial isolate, Sporosarcina pasteurii ATCC-11859, was obtained from the American Type Culture Collection (Manassas, Virginia). A sterile pipet was used to transfer this seed into a culturing medium using a laminar flow hood to reduce the risk of culture contamination. This pre-sterilized culturing broth used an 'ammonium-trypticase soy broth' (NH4 -TSB) growth media which included: tryptic soy broth at $20 \mathrm{~g} / \mathrm{L}$, ammonium sulfate at 10 $\mathrm{g} / \mathrm{L}$, Tris buffer at $0.13 \mathrm{~mol} / \mathrm{L}$, and an overall solution $\mathrm{pH}$ of 9.0. The culture flask was then covered with a pre-sterilized sponge to filter out atmospheric bio-contaminants while still providing oxygen to the culture. A shaking incubator (Innova Model 4000, New Brunswick Scientific) was used to incubate this culture for $48 \mathrm{~h}$ with a continuous shaking speed of $160 \mathrm{rpm}$ at $30^{\circ} \mathrm{C}$. After incubation, this stock microbial culture was then stored at $4^{\circ} \mathrm{C}$ prior for subsequent use. 


\section{Biomass sonication and enzyme extraction}

Urease extraction was completed using a repetitive series of cyclic 'run-cool' (i.e., 10 min 'on' followed by $10 \mathrm{~min}$ 'off') sonication steps. Six such cycles were applied over a two-hour period, with a $150 \mathrm{ml}$ aliquot of the original stock microbial culture being placed directly into a sonication bath (Bransonic Model 220; 120 volt, 125W, and 50/60 kHz). Both continuous and cyclic 'run-cool' sonication modes were evaluated during preliminary scoping studies.

Continuous sonication did produce a release of intracellular urease, albeit with a progressively escalating level of enzyme retardation likely caused by sample heating. Much the same outcome had been reported by Raymond et al. (2011), where a negative denaturing impact occurred with extracted enzymes subjected to prolonged sonication at higher temperatures. Therefore, the cyclic processing mode was adopted given that it provided the lowest temperature buildup (i.e., typically $32-34^{\circ} \mathrm{C}$ ) and highest residual enzyme activity.

The $\mathrm{pH}$, temperature, and volume of each sample were measured during sonication runs, and optical density (OD600) plus microscopic observation was used to qualitatively confirm cell lysis. Fig. 1 depicts the extent of cell lysis typically observed relative to pre- and post-sonication. After completing these tests, the remaining lysed solution was then subjected to a relative centrifugal force of $5500 \mathrm{RCF}$ for $20 \mathrm{~min}$ to separate out residual cellular debris solids from the extracted, soluble urease. This centrifuged free enzyme solution was then diluted to achieve a desired final ureolytic activity as described below. 


\section{Experimental materials}

\section{Sand and silty-sand soil test materials}

Ottawa 20/30 silica sand, as described in ASTM C778 (2014), was used as a coarser soil fraction. This sandy soil material contained more than $98.7 \%$ silica $\left(\mathrm{SiO}_{2}\right)$. The specific gravity, maximum and minimum void ratios $\left(\mathrm{e}_{\max }\right.$ and $\left.\mathrm{e}_{\min }\right)$ of the sand were 2.65, 0.74 and 0.51 , respectively. The sand material was also initially washed with deionized water to remove any soluble chemicals, followed by oven drying at $105^{\circ} \mathrm{C}$ for $24 \mathrm{~h}$ before being tested. A natural loess from Iowa was used in this study as a fine-grained soil. A sieve analysis test and a hydrometer analysis test were conducted to determine the particle sizes of the loess soil. Results showed that loess soil had $0.7 \%$ of sand, $86.5 \%$ of silt, and $12.8 \%$ clay sized particles. The loess soil was sieved through a U.S. Sieve No. 200 (opening $0.074 \mathrm{~mm}$ ) to collect only silt and clay particles. Three soil mixtures were prepared for packing the test soil columns. The test soils were prepared by mixing dry Ottawa sand \#20-30 with oven-dried loess fines to achieve a desired fines content (FC). This percentage of fines content was calculated as the dry mass of silty soil to the sample's total dry soil mass. Three different soil blends were evaluated, including: 1) 100\% sand and $0 \%$ fines, 2) $90 \%$ sand and $10 \%$ fines, and 3) $80 \%$ sand and $20 \%$ fines. These three options are subsequently referred to as: 1) 100-0, 2) 90-10, and 3) 80-20. The material properties and grain size distributions are summarized in Table 2 and Fig. 2, respectively. The 100-0 mixture is classified as poorly graded sand (SP) according to the Unified Soil Classification System (USCS; ASTM 2010). The 90-10 and 80-20 mixtures are identified as poorly graded sand with silt (SP-SM) and silty sand (SM) and both of these mixtures are low plasticity soils based on the Atterberg limits presented in Table 2. The Atterberg limits of the 90-10 and 80-20 
mixtures were similar. The liquid limit (LL) and plastic limit (PL) were conducted by following the ASTM D4318-17 standard which requires that the testing soil must be smaller than the sieve opening size of the No.40 sieve $(0.42 \mathrm{~mm})$. Therefore, all (99\%) of the Ottawa sand \#20-30 (0.85 $\mathrm{mm}-0.6 \mathrm{~mm}$ ) was retained on the No.40 sieve, whereas fine-grained loess soil (smaller than $0.075 \mathrm{~mm}$ ) was collected for LL and PL testing. As both the 90-10 and 80-20 mixtures used Loess soil as the fines, the tests resulted in similar LL and PL for both mixtures.

\section{Experimental procedures}

\section{Soil stabilization column preparation}

Soil stabilization columns were prepared for three different soil mixtures with both sand-only and silty-sand soils. Each specimen was treated with MICP or BEICP to compare the impact of both treatment methods on UCS and permeability. Soil specimens were treated with either 8- 12-, or 16-cycles, given that Inagaki et al. (2011) and Choi et al. (2016) used similar levels of ICP cycling. More detailed information regarding the treatment methodologies will be provided in the next section.

Prior to uploading soils into each test column, the dry soil mixtures were initially mixed with distilled water to achieve 5\% moisture. A moist-tamping method was then used to pack the specimens, where this pre-moistened soil was gently tamped in PVC columns with $50 \mathrm{~mm}$ diameter and $100 \mathrm{~mm}$ height dimensions. To achieve a similar specific density in each layer, predetermined amounts of soil were added in ten successive layers of equal thickness (i.e., at $10 \mathrm{~mm}$ per layer) within each column. These column compaction steps were carefully conducted to 
achieve the similar void ratio (e) levels within all column samples shown previously within Table 2 .

Both upper (inlet) and lower (outlet) ends of each column were then fitted with a pre-cut section of scouring pad material 3-M Scotch Brite Model 7447 to distribute flow streams and avoid clogging. The lower end of each column was also fitted with an additional plastic cap (i.e., glued below the scouring pad section) which had been pre-filled with gravel in order to prevent unwanted loss of the un-stabilized raw soil sample. The schematic diagram of the test set-up is shown in Fig. 3.

\section{Batch column MICP and BEICP treatment procedures}

Two modes of soil stabilization were evaluated using the latter soil columns, including: 1) the BEICP method, and 2) a conventional microbial-based MICP method. A circulated-percolation process was then applied to treat soil columns under partial-saturated condition. The sandy soil and silty-sand soil columns were processed using the following sequential procedure (Fig. 3). First, the catalytic biological solution (either extracted urease for the BEICP method, or bacterial cells for the MICP method), was pumped and recycled into the top of a soil column and gravity drained out from the bottom. The urease activity of the solutions was adjusted to approximately 4-5 $\mathrm{mM}$ urea/min by dilution with deionized water for MICP and BEICP treatment methods. A peristaltic pump (Masterflex Model 77202-50) with silicone tubing (Masterflex Model 96410-16) was used to recirculate this biological liquid for $3 \mathrm{~h}$ with the rate of $0.8-5 \mathrm{ml} / \mathrm{min}$ in order to achieve a $60 \%$ saturation level consistent with prior research by Cheng et al. (2013), which allowed the bacterial cells or extracted enzyme to sorb onto or be trapped onto the soil particle 
surfaces. Second, after the latter $3 \mathrm{~h}$ introduction of the catalytic agents (i.e., either MICP culture or BEICP enzymes), the pore volume biological liquid was drained off the soil column. Third, a mixed chemical solution of urea and calcium chloride $(0.3 \mathrm{M}$ by $1: 1$ ratio) was then introduced and circulated for 9-12 h. Fourth, the soil column was flushed with cyclic deionized water pumping for $2 \mathrm{~h}$ to remove soluble byproducts and then the bottom cap was removed to drain off all liquid for approximately $10 \mathrm{~h}$. After completing this treatment cycle, fresh biological solution and chemical were then introduced and recirculated through the soil column on each successive new cycle. This step-wise approach to introduce enzyme solution (or bacterial cells) and urea/calcium chloride solution was repeated on a 'one cycle per day' routine for either 8,12 , or 16 days total treatment phases. One clarification regarding the MICP testing regime is warranted, with which tests on the low plasticity, silty-sand soil were stopped after 12 cycles because this approach was unable to form fully intact bio-cementation columns. This behavior was attributed to $\mathrm{CaCO}_{3}$ precipitation clogging of the upper portion $(\sim 30 \mathrm{~mm})$ of these specimens. In turn, the middle and bottom parts of these silty-sand MICP-treated samples remained un-solidified and physically unstable.

\section{Analytical procedures}

\section{Culture optical density}

A qualitative assessment of viable biomass optical density (OD) was determined spectrophotometrically at $600 \mathrm{~nm}$ (i.e., OD600) using a visible light spectrophotometer (Hach Model \#DR 3900). 


\section{Urease activity}

Conductivity change was used to measure enzyme activity as ammonium ions were released during urea hydrolysis. The rate of conductivity increase is proportional to the amount of active urease present in the solution. This test was completed with initial $5 \mathrm{ml}$ aliquots of either the bacteria cells or urease solution. After adding $50 \mathrm{ml}$ of a 1-M urease solution, a conductivity meter was used to track the release of ammonium from urea, which exhibited a linear correlation $\left(\mathrm{R}^{2}=0.9979\right)$ between the $\mathrm{NH}_{4}^{+}(\mathrm{Y})$ concentration (in $\left.\mathrm{mM}\right)$ and electric conductivity $(\mathrm{X})$ in milli-Siemens (mS) (Chu et al. 2012):

$$
Y=9.3316 X-0.8198
$$

\section{Stabilized soil permeability}

The permeability of the bio-cemented soil samples was measured by using a constant head method (ASTM D2434-68) with a rigid side-wall device set-up while the samples were still held within the PVC test columns. Prior to the permeability tests, both filters (top and bottom) along with the gravel layer and bottom cap of the column were removed. Tap water $(2 \mathrm{~L})$ was preflushed through the bio-cemented soil samples under $15 \mathrm{kPa}$ back pressure (hydraulic head of about $150 \mathrm{~cm}$ ) to release trapped pore air and to saturate samples before measuring permeability (Cheng et al. 2013). Measurements of untreated sand soil and silty-sand soil permeabilities were also done to compare against the bio-treated specimens. After the initial saturation step, permeability tests were run until steady hydraulic conductivity values $(\mathrm{k})(\mathrm{cm} / \mathrm{sec})$ were reached. Tests were stopped after k of the specimen did not vary more than $20 \%$ (data not shown here for brevity). This state would be reached only if the specimen was fully saturated. 


\section{Stabilized soil unconfined compressive strength}

After measuring the hydraulic conductivity of bio-cemented samples, the columnar PVC molds were cut carefully with a band saw machine to separate the bio-cemented samples. The specimens could stand alone while in a wet condition, which meant that stabilization had occurred. Afterwards, samples were oven dried for $48 \mathrm{~h}$ at a moderate temperature (i.e., $\approx 50^{\circ} \mathrm{C}$ ) to avoid baking clay minerals in silty-sand soil samples (Hawkins and Mcconnell 1992). The unconfined compressive strength (UCS) test was conducted in accordance with ASTM D4219-08. The tests were conducted on samples with a standard size preset by the test column's dimensions (i.e., diameter $\mathrm{D}=50 \mathrm{~mm}$ and height $\mathrm{H}=100 \mathrm{~mm}$ ). A Geotac constant-displacement mode UCS machine was used to shear the samples. The rate of loading was $2 \mathrm{~mm} / \mathrm{min}$. A plastic bag was used to cover each specimen during testing process to collect broken sample materials which were then used for further calcium content analysis (A1 Qabany and Soga 2013).

\section{Stabilized soil calcium carbonate precipitation content}

An acid-rinsed method was used to complete these calcium carbonate measurements, and these tests were completed immediately after the UCS tests (Feng and Montoya 2015). The calcium carbonate content of the stabilized soils was determined according to a percentile weight fraction. Deionized water was initially flushed through cemented specimens to dissolve and flush out any remaining soluble salts. After samples broken down by UCS test, approximately $5 \mathrm{~g}$ of biocemented soil was taken at the middle of soil column, and placed on a fiberglass filter pad. The small specimen and filter was then over-dried at $105^{\circ} \mathrm{C}$ degree overnight. Then, the weights of the dry sample and filter were measured. Afterwards, $1 \mathrm{M} \mathrm{HCl}$ solution was added to dissolve the precipitated calcium carbonate until no bubbles were generated. Finally, that soil (and filter) 
was rinsed with deionized water and oven dried again to determine the dry weight of the acidflushed residual soil (without $\mathrm{CaCO}_{3}$ ). The amount of the precipitated $\mathrm{CaCO}_{3}$ was calculated by the difference between the dry weight (W) of the specimens before (soil $+\mathrm{CaCO}_{3}$ ) and after (soil only) washing in acid $\left(\% \mathrm{CaCO}_{3}=100 \% *\left(\mathrm{~W}_{\text {soil }}+\mathrm{CaCO} 3-\mathrm{W}_{\text {soil }}\right) / \mathrm{W}_{\text {soil }}\right)$.

It should also be noted that the fine-grained silty soil obtained from Iowa loess contained an original $\mathrm{CaCO}_{3}$ content (i.e., $\sim 8 \%$ ), and that it was subsequently necessary to adjust the final $\mathrm{CaCO}_{3}$ content measured with the post-stabilized silty-sand soils relative to this initial amount of silt-based $\mathrm{CaCO}_{3}$. When evaluating the plastic, sand-silt soils, therefore, these pre-stabilization levels of calcium carbonate were $0.8 \%(\mathrm{w} / \mathrm{w})$ for the $90-10$ sample and $1.6 \%(\mathrm{w} / \mathrm{w})$ for the $80-20$ sample. In turn, derivations with BEICP-treated soils had to be adjusted to take into account these original, pre-treatment percentages.

\section{Scanning electron microscope and X-ray diffraction testing}

Scanning electron microscopy (SEM) was used to produce high resolution imagery of the $\mathrm{CaCO}_{3}$ precipitation deposited on tested soil particles with bio-cementation treatment. These SEM analyses were conducted using an FEI Quanta-250 FE-SEM instrument managed by the Iowa State University Materials Analysis and Research Laboratory. During additional X-ray diffraction (XRD) testing, representative bio-cemented samples were pre-crushed and ground before mounting on a glass filter. A Siemens Model D500 diffractometer was used to identify crystal characteristics using comparative evaluation against International Center for Diffraction Data records. 


\section{RESULTS and DISCUSSION}

\section{Urease sonication extraction}

Table 3 presents the final sample temperature, sample volume reduction, optical density, and urease activity results typically observed when using a cyclic 'run-cool' sonication method, as compared to that of the original cultured biomass. These results represent specific outcomes for the conditions of the previously identified sonication hardware, sample size, and operating conditions.

Table 3 showed a slightly increase in temperature and a constant value for $\mathrm{pH}$ after 60 mins of sonication. However, the OD600 values decreased significantly (by $>70 \%$ ) after sonication compared to the control culture. This decrease was correlated to the lysing of bacterial cells (Fig. 1). In addition, the sonication method resulted in a 20 percent volume reduction through evaporation. The 'cyclic run-cool' sonication method typically produced an approximate twofold increase in urease activity (see Table 3's value of $25.4 \mathrm{mM}$ urea per min) as compared to the original whole cell solution. Even then, re-diluting the sample back to a full $150 \mathrm{ml}$ volume would have still resulted in a $20.3 \mathrm{mM} / \mathrm{min}$ activity rate, which was $\sim 75 \%$ higher in urease activity compared to the original culture. This increase in enzyme activity may be due to the lack of transport constraints of the substrate (i.e., urea) through the cell wall in the free enzyme suspension. It should also be noted that these sonicated urease activity rates are either comparable to, or perhaps even higher than, that of the activities reported within many of the previously cited MICP and EICP publications. 
There was an also an element of uncertainty as to whether the obtained sonicated solution may have still contained viable ureolytic cells. However, as mentioned previously, microscopic observation showed only nominal levels of lingering intact cells following sonication. Furthermore, the sonicated solution was centrifuged to remove residual cellular material, and pre- and post-centrifuge activity testing showed less than $1 \%$ difference. Furthermore, specific SEM observation of BEICP-stabilized sands showed no indication of the surficial $\mathrm{CaCO}_{3}$ buildup typically observed with viable cell activity during MICP processing (i.e., see upcoming Fig. 7).

\section{MICP versus BEICP stabilization of sandy soil}

The MICP and BEICP methods were comparatively evaluated with the treatment of sand-only test columns which received 8,12 or 16 repetitive treatment cycles in order to achieve different levels of calcium carbonate content. A complete set of tabular testing results for all of the MICP and BEICP tests is provided in Table 4, covering both sand-only and silty-sand samples.

Figs. 4 and 5 present the comparison of these MICP and BEICP methods on sandy soil in terms of strength and permeability. In both cases, these data are presented in relation to the associated levels of $\mathrm{CaCO}_{3}$ precipitation measured according to treatment cycle numbers. In addition, Fig.6 shows the comparison of the efficiencies of increase in UCS and reduction in permeability between both methods. The following SEM photographs given in Fig. 7 then provide a visual perspective of the stabilized sand products generated with these alternative methods. 


\section{Unconfined compressive strength tests with MICP and BEICP treated sandy soil}

Fig. 4 demonstrates that the MICP process consistently produced a higher unconfined compressive strength (UCS) for the same number of treatment cycles as compared to the BEICP treatment, while at the same time realizing a higher level of calcium carbonate precipitation. After 16 cycles, and as recorded in Table 4, the mean UCS values for MICP- and BEICP-treated samples were respectively $1,960 \mathrm{kPa}$ and $1,691 \mathrm{kPa}$.

These strength and $\mathrm{CaCO}_{3}$ precipitation levels with MICP stabilization were similar to those reported during three preceding MICP studies (van Paassen et al. 2010; Al Qabany and Soga 2013; Cui et al. 2017). Yasuhara et al. (2012) also conducted four and eight-cycle EICP stabilization tests on sandy soil that provided a comparable range of unconfined strength from $\sim 400 \mathrm{kPa}$ to $\sim 1,600 \mathrm{kPa}$.

These higher UCS and $\mathrm{CaCO}_{3}$ precipitation levels achieved at each of the cycling levels with MICP versus BEICP suggest that viable MICP cells have a higher level of entrapment, binding, and sorption leading to subsequently higher levels of calcite formation than was the case with the smaller, soluble BEICP enzyme catalysts. A further characterization of the apparent stabilization 'efficiency', though, can also be derived by comparing UCS levels at roughly comparable $\mathrm{CaCO}_{3}$ precipitation levels, where these data appear to suggest a higher UCS outcome with BEICP processing.

\section{Permeability tests with MICP and BEICP treated sandy soil}

The permeability results given in Fig. 5 are again presented in relation to calcium carbonate precipitation results produced with samples being treated by either MICP or BEICP procedures. 
The original untreated sand had an initial permeability of $\sim 10^{-1} \mathrm{~cm} / \mathrm{s}$. In either case, a progressive reduction in permeability of sand treated by increased numbers of stepwise MICP and BEICP steps would be expected following the precipitation of calcium carbonate which had clogged previously open pore space (Nemati and Voordouw 2003; Whiffin et al. 2007). MICP treatment achieved nearly a three-log final decline after 16-cycle treatment. Note also that Fig. 5 plots relative error values for permeability (see Table 4). As described by Baird 1994, relative error was calculated by the following equation: Relative error $=(0.434) \mathrm{x}$ (permeability standard deviation / average permeability).

For MICP-treated samples, these permeability data are similar to the results reported by Al Qabany and Soga (2013) and Choi et al. (2016) when using the same concentration of chemical solutions and when accumulating similar levels of calcium carbonate precipitation. For BEICP processing, though, the decline in permeability was distinctly different, with only an approximate one-log decrease even after the sixteenth cycle step. These BEICP permeability changes were also noticeably different (i.e., where BEICP produced a more permeable result) than had been previously reported by Yasuhara et al. (2012). However, Yasuhara et al. (2012) used a higher concentration of substrate urease and calcium source solutions than was the case with this research. Assumedly, the increased supply of urease and calcium chloride solutions used by these authors would have led to a higher degree of precipitate formation which then resulted in the greater reduction in permeability.

On the other hand, the progressively decreased permeability of MICP-based stabilization represents an inherent disadvantage for these cyclic, stepwise ICP methods given that increasing 
pore space clogging will then retard the desired transport of the operative urease-bearing bacterial cells. This sort of MICP limitation has been noted by Whiffin et al. (2007) and van Paassen (2009), where the migration of urease-bearing microbes away from the point of injection would be limited, and that in turn their ability to form uniformly cemented samples would be constrained. Conversely, BEICP's ability to stabilize sands without imposing nearly as much permeability reduction would be favorable, since it would allow further cycles of treatment if desired to achieve higher stabilization levels.

\section{Comparison of efficiency of increase in UCS and permeability reduction between MICP and BEICP methods}

Fig. 6 compares the efficiency of MICP and BEICP methods in terms of strength gain and permeability reduction on sandy soils. The efficiency of UCS increase rate was determined using the ratio of the increment of mean increase of UCS to the increment of mean increase in $\mathrm{CaCO}_{3}$ content (Fig. 6a) while the efficiency of permeability reduction was calculated by ratio of the reduction in permeability to the increase in $\mathrm{CaCO}_{3}$ content (Fig. 6b). For example, the efficiency of increase in UCS of BEICP-treated sandy soil sample from 8 to 12 cycles was computed as $\left(\mathrm{UCS}_{\text {cycle12 }}-\mathrm{UCS}_{\text {cycles }}\right)(\mathrm{kPa}) /\left(\mathrm{CaCO}_{3 \text { cycle12 }}-\mathrm{CaCO}_{3 \text { cycle } 8}\right)(\%)$. Similarly, the efficiency of permeability reduction of the sample from 8 to 12 cycles was determined as $\mid\left(\right.$ permeability $y_{\text {cycle } 12}-$ permeability cycle 8$)(\mathrm{cm} / \mathrm{s}) \mid /\left(\mathrm{CaCO}_{3 \text { cycle12 }}-\mathrm{CaCO}_{3 \text { cycles }}\right)(\%)$.

In general, the increase rate of UCS in sandy soils obtained with BEICP method is higher than those observed with MICP method. It is apparent that the ratio of UCS to $\mathrm{CaCO}_{3}$ content in BEICP-treated samples is approximately 1.5 to 2 times higher than those observed with MICP- 
treated samples. It is reasonable to suspect that the observed higher efficiency with BEICPtreated specimens is due to the precipitation of $\mathrm{CaCO}_{3}$ mainly at contact points of sand grains, whereas the $\mathrm{CaCO}_{3}$ was formed on particle-particle contacts and filled void space of the sand matrix during MICP treatment. This agrees with the findings of previous studies which stated that the calcite concentrated at interparticle connection points are the ones that mainly contribute to the strength improvement in soils (Cheng et al. 2012; DeJong et al. 2010). Furthermore, it was observed that the strength gain efficiency of both systems were more similar at higher treatment cycles. The reduction in the UCS increase rate with higher treatment cycles is the result of saturation of sandy soils by $\mathrm{CaCO}_{3}$. Although BEICP method provided a higher UCS rate increase than MICP, it was clear that MICP treatment reduced the permeability of sandy soils to a greater degree than BEICP treatment, particularly with higher cycles of treatment (Fig. 6b). The efficiency of permeability reduction of MICP-treated samples was slightly higher than BEICP-treated specimens at 8 and 12 cycles and was doubled at 16 cycles of treatment. The higher permeability reduction observed with MICP treated sandy soil was due to higher level of $\mathrm{CaCO}_{3}$ precipitation which filled the void space of the sand matrix. This is described in detail in the following section.

\section{SEM and XRD analyses with MICP and BEICP treated sandy soil}

Fig. 7 shows a series of SEM images for MICP- and BEICP-treated sands after eight and sixteen cycles of treatment, respectively. These images provide a visual perspective of the distribution, size, and packing density of the ICP-precipitated crystals which in turn led to the changes in strength and permeability of the stabilized sands discussed previously. Figs. $7 \mathrm{a}$ and $7 \mathrm{~b}$ 's MICP 
results show a considerably more highly populated and widely distributed extent of precipitate presence than is the case with Figs. 7c and 7d's BEICP-treated sands, which corresponds well with the preceding results for MICP's higher $\mathrm{CaCO}_{3}$ content (i.e., see Table 4). The higher density of crystal precipitation with the MICP versus BEICP surfaces and void space also offers a qualitative correlation with the MICP-treated sand's higher UCS and reduced permeability. These results suggest that the microbial cells responsible for MICP treatment have a higher degree of surficial attachment than that of BEICP's enzyme catalysts, where there are likely physical, chemical, and even biochemical mechanisms that improve bacterial adhesion at a higher and more widely distributed extent than is the case with the smaller, soluble BEICP enzyme. One such mechanism for MICP treatment, where there is a higher cell affinity for sand surfaces, would be that of exocellular polysaccharide polymers surrounding microbes that might well increase surficial cell adhesion. A further observation with these MICP images is that their higher deposition of $\mathrm{CaCO}_{3}$ crystals on exterior and internal void surfaces of the sand particles would then provide an even higher area for further successive attachment with each following treatment cycle.

For MICP, deposition initially takes place at three locations, including: 1) points of localized sand grain contact, 2) within the sand's internal pore space, and 3) on the surrounding sand surface area. Fig. 7a's schematic location of these points of crystal deposition are stylized with white crystals which contribute to UC strengthening (i.e., located at the points of sand grain contact and binding). Fig. 7a's darker (blue) crystals, depositing on the sand void space, would also contribute to reducing matrix permeability. It should be noted, though, that these schematics are simplified to the extent that they do not depict the additional $\mathrm{CaCO}_{3}$, which further attaches 
to the sand surfaces, although this deposition is visually evident within the SEM photos. Further $\mathrm{CaCO}_{3}$ deposition with higher treatment cycles (i.e., see Fig. $7 \mathrm{~b}$ for sixteen cycles) again happens at both surface and pore space locations, such that the overall $\mathrm{CaCO}_{3}$ content continues to escalate and the pore space volume (and permeability) steadily reduces. As this phase of treatment is reached, though, there is likely more than a nominal fraction of the crystal deposition which is not necessarily helping to improve stability.

With BEICP, however, the initial deposition appears to happen almost exclusively at the points of sand grains contact (see Fig. 7c). Conceivably, this behavior stems from physical trapping and crystal nucleation by the urease enzyme within this confined space. A similar calcium carbonate precipitation pattern was observed by Simatupang and Okamura (2017) in specimens treated by the EICP method. After eight cycles, the permeability of our BEICP-treated sample remained high, likely resulting in wash out of the solution from the sand's internal pore space. Therefore, there is no $\mathrm{CaCO}_{3}$ precipitated at the sand grain gaps. As this deposition then continues through successive treatment cycles (i.e., see Fig. 7d for sixteen cycles), continued accumulation occurs at both the contact points and internal void space. In this case, therefore, further pore volume filling and resulting permeability reductions could be expected; however, the SEM images of BEICP-treated specimens (see Figs. 7c and 7d) indicated that this rate of buildup would be far lower than would happen during MICP cycling (see Figs. 7a and 7b).

Fig. 8 displays the XRD spectrum of MICP- and BEICP-treated sandy soil samples. As is clearly shown in XRD analysis data, a distinct peak of calcite was observed in the treated specimens indicating that calcite was precipitated in biocemented sand through both MICP and BEICP 
treatment methods. The peak of calcite from XRD analysis was reported in previous MICP ( Li et al. 2015; Choi et al. 2017) and EICP (Yasuhara et al. 2012; Hamdan et al. 2013) studies. These results therefore confirm that the free bacterial urease is able to produce calcium carbonate for improving sandy soil strength via the ICP process.

\section{BEICP stabilization of silty-sand soil}

The following details and discussion for silty-sand treatment are limited to BEICP-only results since as shown previously in Table 3 the MICP treatment (at least using a twelve cycle method) proved to be not possible once a fine grain fraction had been added at either a $10 \%$ or $20 \%$ level. Bio-clogging did occur during these MICP tests, but only at the column's inlet point where complete void plugging then stopped deeper penetration of the stabilization effect. The successful capability for BEICP processing to stabilize a full-depth sample column of silty-sand soils, though, is visually confirmed by the accompanying photograph given in Fig. 9 (e.g., after an eight-cycle treatment).

As with the preceding tests completed on sand-only materials, these BEICP silty-sand tests were conducted with 8,12 , and 16 cycle step options, and the resultant UCS, stress-strain and permeability outcomes are presented in Table 4 and Figs. 10, 11 and 12. A subsequent set of SEM images are also provided for these tests, as well as XRD results used to identify mineral compositions for both the original silt material plus the stabilized products. 


\section{Unconfined compression strength with BEICP treated silty-sand soils}

The observed pattern of UCS buildup relative to $\mathrm{CaCO}_{3}$ precipitation with these BEICP siltysand tests was similar to what was seen with the sand-only tests (Fig. 10), where UCS increased with successive treatment cycle numbers. These results warrant multiple points of discussion. First, these silty-sand BEICP results for UCS were lower than the ones observed with the sandonly tests. Second, these BEICP silty-sand results for UCS at each of the cyclic step intervals declined as the fine grain fraction increased. Third, the latter decrease in UCS after 16 cycles was occurring even though the $\mathrm{CaCO}_{3}$ deposition was increasing to levels higher than those observed during the sand-only tests (e.g., mean $\mathrm{UCS}=1,118 \mathrm{kPa}$ at 16 cycles for the $90-10$ sand-silt mix, and mean $\mathrm{UCS}=842 \mathrm{kPa}$ at 16 cycles for the 80-20 sand-silt mix). This trend towards lower UCS values with higher silt fractions was similarly observed by Gomez and DeJong (2017), although in their case the measured calcite levels did not show the same tendency towards higher buildup. On the other hand, Kavazanjian and Hamdan (2015) observed a similarly increased level of $\mathrm{CaCO}_{3}$ formation with EICP processing after adding bentonite to sand. Interestingly, though, their EICP tests were not able to form an intact, stabilized column. Oliveira et al. (2016) similarly reported elevated $\mathrm{CaCO}_{3}$ precipitation levels (reaching 17\%) being developed during plant-based EICP tests on a heavily compacted sand-silt-clay soil mixture (i.e., at respective $73.4 \%, 23.8 \%$, and $2.8 \%$ silt levels), and here again their finished product UCS (i.e., $\sim 250 \mathrm{kPa}$ ) was low. Soon et al. (2014) also reported similarly low UCS results for MICP treatment of siltysand soils, ranging from 66 to $152 \mathrm{kPa}$. The results of the current study indicate that the BEICP is a promising method to treat silty sand soils. 
Fig. 11. presents the typical stress-strain curves of the bio-stabilized specimens at 12 treatment cycles. For sandy soil, although the MICP-treated sample (M100-0-12) provided higher UCS than BIECP-treated sample (B100-0-12), their patterns of stress-strain are similar. Once the peak strength was reached, these stabilized sandy specimens experienced a sharp drop in stress within a small strain range $(\sim 0.6 \%)$, indicating a typical mechanical behavior of brittle materials. However, BEICP-treated silty sand soil showed a different pattern of stress-strain behavior. After its initial linear increase, the stress of BEICP-treated silty sand samples continues to increase until the peak stress point, at which point the sample softening occurs before its final drop. The presence of fine grains in pore spaces decreases friction amongst the host sand particles, facilitating their subsequent displacement. While the strength of these stabilized sand-silt samples is reduced by increase the fines percentage, the higher fines presence increases the treated sample's ductility. These findings are consistent with the results published by Oliveira et al. (2016).

\section{Permeability tests with BEICP treated silty-sand soils}

The BEICP permeability results for silty-sand treatment given in Fig. 12 include both values for raw, untreated materials and final, stabilized conditions. Here again, this figure plots relative error values for permeability (see Table 4). As would be expected, the silty-sand findings generally exhibited an approximate one-log reduction in permeability than had been seen with the sand-only tests, where there was a combined effect of pore plugging due to silt presence plus $\mathrm{CaCO}_{3}$ deposition. Of course, the further accumulation of calcite crystals which occur with repetitive treatment cycles for these stabilization procedures will further increase pore clogging 
and permeability reduction (Chu et al. 2012). BEICP treatment with the 90-10 soil mix showed an approximate two-log decline in permeability, and the 80-20 sample was somewhat higher at about a three-log difference. Again, these reductions are occurring with far higher levels of $\mathrm{CaCO}_{3}$ deposition, where the combined impacts of void space plugging due to both silt presence and co-enmeshed $\mathrm{CaCO}_{3}$ precipitation were responsible for this higher hydraulic plugging.

\section{SEM and XRD analyses with BEICP treated silty-sand soils}

Fig. 13 presents two SEM images, plus accompanying schematics, which collectively depict the high-level deposition of $\mathrm{CaCO}_{3}$ crystals within both the 90-10 (Fig. 13a) and 80-20 (Fig. 13b) samples, after just eight BEICP cycles. The fact that the sample used for these SEM observations was pulled from a mid-depth location on a test column adds a further visual validation to Fig. 9's perspective of full sample solidification. In addition, these images show a widely distributed level of $\mathrm{CaCO}_{3}$ precipitation. Fig. 13 also indicates that sizable pore space deposition was taking place in the presence of silts as compared to that of the BEICP-treated sand-only sample (Figs. 7c and 7d). This pore space filling was no doubt due to the combined presence of both silt fines and the BEICP-formed $\mathrm{CaCO}_{3}$ deposit. Collectively, the Figs. 13a and 13b images visually suggest that the BEICP process is binding together fine grain soils and precipitated calcite crystals into a cemented-bridge structure whose linkage then stabilizes the predominate sand grain matrix.

With BEICP treatment of the $90-10$ soils (Fig. 13a), this stabilized product appears to involve a partial, and yet not complete, separation of the individual sand grains. In turn, this behavior implied that there was still some measure of $\mathrm{CaCO}_{3}$ deposition at the remaining points of direct 
sand contact, as well as additional deposition taking place at both surficial and void space locations. However, once the fine soil addition reached the 80-20 level (Fig. 13b), it appeared that the fine silt particles had produced a nearly full physical separation of the coarse sand grains. This observation is in general agreement with previous studies on the intergranular soil mix classification and the influence of fines content on stress-strain behavior of silty sand (Lade and Yamamuro 1997; Yamamuro and Lade 1998; Thevanayagam et al. 2002). In turn, a considerable portion of the $\mathrm{CaCO}_{3}$ deposition with the 80-20 samples would not have been in a position to directly strengthen the coarse sand soil skeleton. It is also noteworthy that these SEM images for silty-sand BEICP treatment, and their almost veneer-like thin surficial coating of $\mathrm{CaCO}_{3}$ crystal deposition, were quite similar to the SEM imagery shown by Kavazanjian and Hamdan (2015) for EICP treatment of a sand-bentonite system.

The additional presence of the fine-grain particles within a sand-silt mixture will clearly impact the mechanisms and efficacy of these applied ICP processes. Notably, higher silt levels (i.e., 8020 versus 90-10) led to a lower product UCS value (see Table 4), since it appeared that direct calcite bridging at sand-sand contact points was reduced (Fig. 13b). Furthermore, the higher void deposition with calcite and silt further reduced permeability.

These impacts could be expected to involve a far more complex array of overlapping physical, chemical, and even biological factors versus that of much less complicated sand-only mixtures. The physical aspects will involve particle inter-mixing, orientation, spacing, void sizing and deposition, etc. Yet another group of chemical considerations will also come into play given the exceedingly more complex and reactive nature of the additional non-sand soil materials (i.e., 
involving redox, acid-base, chelation, sorption, buffering, etc. reactions which will occur in parallel with ICP's primary precipitation process). Adding in yet another likely set of biological issues which will escalate in importance along with these preceding factors (e.g., involving biotransport, oxidation and reduction, surficial adhesion and attachment, etc.), silty-sand soil processing will be far more complicated that had been previously considered with basic sandonly MICP treatment.

This respective presence of deposited calcium was confirmed using further XRD analysis as shown in Fig. 14. In the XRD spectra, the peak of calcite in the BEICP-treated specimen (Fig. $14 \mathrm{~b}$ and c) was significantly higher than the untreated fine grained soils (Fig. 14a). This is consistent with the XRD results obtained from BEICP-treated sandy soil. It is therefore evident that the BEICP technique resulted in calcium carbonate formation that bridged coarse and fine grain soil.

\section{SEM-based perspectives on ICP calcite crystal morphology}

Three additional points about the size and morphology of the ICP calcite formation observed during these tests can be drawn from the following Fig. 15 (SEM images and accompanying schematics). The most highly magnified Fig. 15a image for eight-cycle MICP results shows crystal sizes which range between single-digit micron and $\sim 8$ to $10 \mu \mathrm{m}$ levels, while the Fig. $15 \mathrm{~b}$ image for eight-cycle BECIP shows a noticeably smaller crystal size (i.e., typically $\sim 1-4 \mu \mathrm{m}$ ). The size and morphology of calcium carbonate crystals precipitated via ureolytic bacteria were investigated in several previous studies (Mitchell and Ferris 2005, 2006a; b; Stocks-Fischer et al. 1999). In general, bio-induced calcite formation involves nascent seed nucleation within alkaline 
micro-environments surrounding ureolytic bacteria cells and/or free enzymes followed by progressive crystal expansion. In MICP, Mitchell and Ferris (2006b) reported the mean value of crystal diameter as $4.2 \mu \mathrm{m}$ after a one-day reaction period, which then enlarged to $7.4 \mu \mathrm{m}$ after a one-week duration. In contrast, nucleation of calcite on enzyme surfaces, such as in BEICP, results in much smaller nano-sized crystals. Sondi and Salopek-Sondi (2005) noted that vaterite and calcite precipitates initially formed by ureases purified from $S$. pastuerii were estimated to be approximately $20 \mathrm{~nm}$ in diameter. Tong et al. (2004) also reported a range of sizes for seed micro-crystals formed on amino acids as being 3 to $150 \mathrm{~nm}$. A similar phenomenon likely occurred in the BEICP samples shown in Fig. 15, resulting in smaller crystals formed compared to MICP treatment.

Once BEICP processing has been continued for sixteen-cycles, though, the corresponding Fig. $15 \mathrm{c}$ image shows that these crystals had escalated in size to an even larger scale comparable to that of MICP's level. The available evidence for an apparent difference in precipitate crystal sizes for MICP and BEICP is admittedly tentative at this point. However, the possibility for this sort of difference in crystal formation and size is consistent with findings reported by other MICP and EICP researchers (Whiffin et al. 2007; Al Qabany and Soga 2013; Cheng et al. 2013; Choi et al. 2016), where a number of inter-related factors may be responsible (e.g., substrate and calcium salt solution concentrations, cycling numbers, urease activity rates, upflow versus downflow cyclic flow patterns and related degree of void space saturation, etc.).

A second perspective revealed by these Fig. 15 images for BEICP processing is that there appears to be a preferential pattern for BEICP's precipitating $\mathrm{CaCO}_{3}$ formation at the contact 
points between sand particles. On the other hand, the 8- and 16-cycle MICP imagery (see Figs. 7a and 7b) shows an overlapping crystal buildup on sand surfaces where the $\mathrm{CaCO}_{3}$ coverage produces even higher UCS. While the same impact of additional BEICP crystal deposition between 8- and 16-cycles also leads to a similar increase in higher UCS, the BEICP process notably has a lower net calcite accumulation. In turn, there is distinctly lower level of void volume deposition taking place with BEICP's reduced calcite deposition, such that the stabilized soil's permeability remains far higher than with MICP processing at similar treatment cycles.

The third point regarding BEICP calcite formation behavior which might be made on the basis of Fig. 15e's silty-sand SEM image, relative to the location at which calcite appears to be preferentially forming. Notably, calcite deposition is taking place away from the silt particles, in a fashion which suggests that the enzyme passage had selectively followed a streamline through the sample's more permeable void space and not through the far less permeable silt-rich zones. Jenneman et al. (1982) mentioned much the same tendency of bacterial flow through porous sandstone to proceed through high-permeability zones versus low-permeability zones.

\section{CONCLUSIONS}

A core outcome with this research is that a bacterial enzyme induced calcite precipitation (BEICP) process can be applied using a relatively easily obtained cellular enzyme extract, and that this method is able to biostabilize both non-plastic sand as well as low plasticity silty-sand materials. In turn, the following set of bullet-listed conclusions are correspondingly offered:

- Intracellular urease enzymes can be effectively extracted for subsequent BEICP treatment using an expedient (approximately 2 h) cyclic run-cool sonication method, 
- These extracted, soluble enzymes for BEICP processing achieved solidified, stabilized outcomes with non-plastic sand plus low plasticity 90-10 and 80-20 (i.e., respective sand and silt percentages) soil materials, and that the UC strength progressively increased with successive BEICP treatment cycles,

- Slightly lower UC strength levels were achieved with BEICP versus MICP processing of sand-only soils, although BEICP achieved this strength at lower level of $\mathrm{CaCO}_{3}$ deposition,

- SEM observations showed that $\mathrm{CaCO}_{3}$ deposition with BEICP treatment of sand-only soils predominantly occurred at the contact points for the sand grain skeleton, as compared to a far wider distribution of this precipitate during MICP treatment which spread across the sand surface as well as within the sand pore space,

- There was a distinct difference in the permeability outcome with BEICP processing as compared to MICP treatment, with less of a reduction in permeability with successive treatment cycles during both sand-only and silty-sand processing,

- The presence of additional fine silt soil particles could be successfully handled during BEICP stabilization, but that this did result in a corresponding UC strength reduction when compared to that of sand-only treatment at similar BEICP treatment cycles,

- SEM observations of BEICP treated silty-sand materials showed a far more widely spread deposition of $\mathrm{CaCO}_{3}$ than had been seen with sand-only processing, both on exterior grain surfaces and internal void spaces, and

- The latter increase in BEICP-generated $\mathrm{CaCO}_{3}$ deposition on silty-sand soils resulted in a further reduction of permeability than had been the case with sand-only treatment, but 
that the remaining permeability would likely have allowed for further cyclic treatment to secure even higher UCS outcomes.

\section{FUTURE RESEARCH RECOMMENDATIONS}

The following recommendations are constructively offered in terms of possible future research avenues intent on further elucidating this paper's BEICP concept:

- Further advancements with characterizing and optimizing the procurement, performance, and behavior of the urease catalyst used during BEICP are warranted. For example, an improved means should be developed to quantify sonicated urease activities based on specific activity relative to the extracted enzyme's relative protein mass, as a means of further understanding the enzyme activity beyond a mere substrate depletion rate. In addition, the sorption properties of these free enzymes should also be characterized.

- More detailed comparative assessment of the BEICP, MICP and EICP methods is warranted in terms of cost, application complexity and challenges, overall efficiency, etc.

- Shear strengths of BEICP and MICP treated specimens should be investigated under different saturation levels, including fully saturated conditions. Triaxial testing would particularly beneficial in terms of allowable control over the degree of saturation with each specimen.

- Further optimization assessment for the BEICP concept is warranted. For example, tolerable and optimal environmental conditions need to be evaluated (e.g., for freezethaw, wet-dry, moisture, temperature, etc. parameters), field application methods need to be developed for urease production, handling, storage, application, etc. 


\section{REFERENCES}

Al Qabany, A., and Soga, K. 2013. "Effect of chemical treatment used in MICP on engineering properties of cemented soils." Geotechnique, 63(4), 331-339.

ASTM. 1996. "Standard test method for unconfined compressive strength index of chemical grouted soil." ASTM D4219 - 08, 1-6.

ASTM. 2006. "Standard test method for permeability of granular soils (constant head)." ASTM D2434-68, 68 (Reapproved), 1-5.

ASTM. 2010. "Standard practice for classification of soils for engineering purposes (Unified Soil Classification System).” ASTM D2487 - 10, i, 1-12.

ASTM. 2014. "Standard specification for sand.” ASTM C778, 1-3.

ASTM. 2017. "Standard test methods for liquid limit, plastic limit, and plasticity index of soils." ASTM D4318 - 17, 04(June 2017), 1-14.

Baird, D. C. 1994. Experimentation: An introduction to measurement theory and experiment design. (R. Henderson, ed.), Prentice-Hall, Inc., New Jersey.

Bang, S. S., Bang, S. S., Frutiger, S., Nehl, L. M., and Comes, B. L. 2009. “Application of novel biological technique in dust suppression." Proc., Transportation Research Board 88th Annual Meeting, Transportation Research Board (CD-ROM), Washington, DC, USA, DC, USA, 6-7.

Bang, S. S., William, A. E., and Ramakrishnan, V. 2001. “Application of an enzyme immobilization technique in calcite precipitation." The 13th International Symposium on Microencapsulation, Angers, France, France, Oral communication O-12.

Burbank, M. B., Weaver, T. J., Green, T. L., Williams, B. C., and Crawford, R. L. 2011. 
"Precipitation of calcite by indigenous microorganisms to strengthen liquefiable soils." Geomicrobiology Journal, 28(February), 301-312.

Cheng, L., Cord-Ruwisch, R., and Shahin, M. A. 2012. "Cementation of sand soil by microbially induced calcite precipitation at various degrees of saturation.” Can. Geotech. J., 50, 81.

Cheng, L., Cord-Ruwisch, R., and Shahin, M. A. 2013. "Cementation of sand soil by microbially induced calcite precipitation at various degrees of saturation." Canadian Geotechnical Journal, 50(1), 81-90.

Choi, S.-G., Wang, K., and Chu, J. 2016. "Properties of biocemented, fiber reinforced sand." Construction and Building Materials, Elsevier Ltd, 120, 623-629.

Choi, S. G., Chu, J., Brown, R. C., Wang, K., and Wen, Z. 2017. "Sustainable biocement production via microbially induced calcium carbonate precipitation: use of limestone and acetic acid derived from pyrolysis of lignocellulosic biomass.” ACS Sustainable Chemistry and Engineering, 5(6), 5183-5190.

Chu, J., Stabnikov, V., and Ivanov, V. 2012. "Microbially induced calcium carbonate precipitation on surface or in the bulk of soil." Geomicrobiology Journal, 29(March), 544549.

Cui, M. J., Zheng, J. J., Zhang, R. J., Lai, H. J., and Zhang, J. 2017. "Influence of cementation level on the strength behaviour of bio-cemented sand." Acta Geotechnica, Springer Berlin Heidelberg, 12(5), 971-986.

Dakhane, A., Das, S., Hansen, H., O’Donnell, S., Hanoon, F., Rushton, A., Perla, C., and Neithalath, N. 2018. "Crack healing in cementitious mortars using enzyme-induced carbonate precipitation: Quantification based on fracture response." Journal of Materials in 
Civil Engineering, 30(4), 1-10.

De Jong, J. T., Martinez, B. C., Mortensen, B. M., Nelson, D. C., Waller, J. T., Weil, M. H., Ginn, T. R., Weathers, T., Barkouki, T., Fujita, Y., Redden, G., Hunt, C., Major, D., and Tanyu, B. 2009. "Upscaling of bio-mediated soil improvement." Proceedings of the 17th International Conference on Soil Mechanics and Geotechnical Engineering: The Academia and Practice of Geotechnical Engineering, 3, 2300-2303.

DeJong, J. T., Mortensen, B. M., Martinez, B. C., and Nelson, D. C. 2010. “Bio-mediated soil improvement.” Ecological Engineering, 36, 197-210.

Dilrukshi, R. A. N., Watanabe, J., and Kawasaki, S. 2016. "Strengthening of sand cemented with Calcium Phosphate Compounds using Plant-derived Urease.” International Journal of Geomate, Japan, 11(25), 2461-2467.

Feng, K., and Montoya, B. M. 2015. "Influence of confinement and cementation level on the behavior of microbial-induced calcite precipitated sands under monotonic drained loading." Journal of Geotechnical and Geoenvironmental Engineering, 2, 1-9.

Ferris, F. G., and Stehmeier, L. G. 1991. "Bacteriogenic mineral plugging.” Canada.

Ferris, F. G., Stehmeier, L. G., Kantzas, A., and Mourits, F. M. 1991. “Bacteriogenic mineral plugging." Proc., 4th Petroleum Conference of the South Saskatchewan Section, The Petroleum Society of CIM, Husky Oil Operation Ltd., Calagy, Regina, Sask, Canada, Canada, 11-1-11-12.

Gomez, M. G., and DeJong, J. T. 2017. "Engineering properties of bio-cementation improved sandy soils." Grouting 2017 GSP, 23-33.

Gomez, M. G., Martinez, B. C., DeJong, J. T., Hunt, C. E., deVlaming, L. A., Major, D. W., and 
Dworatzek, S. M. 2015. "Field-scale bio-cementation tests to improve sands." Proceedings of the Institution of Civil Engineers - Ground Improvement, 168(3), 206-216.

Hamdan, N., and Kavazanjian, E. 2016. "Enzyme-induced carbonate mineral precipitation for fugitive dust control." Géotechnique, 66(7), 546-555.

Hamdan, N., Kavazanjian, J. E., and S., O. 2013. “Carbonate cementation via plant derived urease." Proceedings of the 18th International Conference on Soil Mechanics and Geotechnical Engineering, Paris 2013, 2489-2492.

Hamdan, N., Zhao, Z., Mujica, M., Kavazanjian, E. J., and He, X. 2016. "Hydrogel-assisted enzyme-induced carbonate mineral precipitation." Journal of Materials in Civil Engineering, 25(October), 864-870.

Handley-Sidhu, S., Sham, E., Cuthbert, M. O., Nougarol, S., Mantle, M., Johns, M. L., Macaskie, L. E., and Renshaw, J. C. 2013. "Kinetics of urease mediated calcite precipitation and permeability reduction of porous media evidenced by magnetic resonance imaging." International Journal of Environmental Science and Technology, 10(5), 881-890.

Hawkins, A. B., and Mcconnell, B. J. 1992. "Sensitivity of sandstone strength and deformability to changes in moisture content." Quarterly Journal of Engineering Geology and Hydrogeology, 25, 115-130.

Inagaki, Y., Tsukamoto, M., Mori, H., Sasaki, T., Soga, K., Qabany, A. A., and Hata, T. 2011. "The influence of injection conditions and soil types on soil improvement by microbial functions." ASCE Geo-Frontiers, 4021-4030.

Jenneman, G. E., Knapp, R. M., Menzie, D. E., McInerney, M. J., Revus, D. E., Clark, J. B., and Munnecke, D. M. 1982. “Transport phenomena and plugging in Berea sandstone using 
microorganisms.” Proc. Int. Conf. Microbial Enhanced Oil Recovery, Afton, OK, US, 7175.

Jiang, N. J., Yoshioka, H., Yamamoto, K., and Soga, K. 2016. "Ureolytic activities of a ureaseproducing bacterium and purified urease enzyme in the anoxic condition: Implication for subseafloor sand production control by microbially induced carbonate precipitation (MICP).” Ecological Engineering, 90, 96-104.

Jiang, N., Soga, K., and Kuo, M. 2017. "Microbially induced carbonate precipitation for seepage-induced internal erosion control in sand - clay mixtures.” Journal of Geotechnical and Geoenvironmental Engineering, 143(3), 1-14.

Kantzas, A., Stehmeier, L., Marentette, D. F., Ferris, F. G., Jha, K. N., and Mourits, F. M. 1992. "A novel nethod of sand consolidation through bacteriogenic mineral plugging." Proc., 43rd Annual Technical Meeting, The Petroleum Society of CIM, CIM Journals, Calgary, Canada, 46-1-46-15.

Kavazanjian, E., and Hamdan, N. 2013. "Mineral precipitation methods.” Arizona Board of Regents, A Body Corporate of The State of Arizona, Acting for and on Behalf of Arizona State University, U. S. Patent 20160236943 A1, Filling date: October 28, 2013.

Kavazanjian, E., and Hamdan, N. 2015. "Enzyme induced carbonate precipitation (EICP) columns for ground improvement.” Proc., ASCE IFCEE 2015, M. Iskander, M. T. Suleiman, J. B. Anderson, and Debra F. Laefer, eds., ASCE, San Antonio, Texas, 22522261.

Kavazanjian, E. J., Almajed, A., and Hamdan, N. 2017. "Bio-inspired soil improvement using EICP soil columns and soil nails." Grouting 2017 GSP, 13-22. 
Lade, P. V, and Yamamuro, J. a. 1997. "Effects of nonplastic fines on static liquefaction of sands." Canadian Geotechnical Journal, 34(6), 918-928.

Larsen, J., Poulsen, M., Lundgaard, T., and Agerbaek, M. 2008. "Plugging of fractures in chalk reservoirs by enzymatic-induced calcium carbonate precipitation.” SPE Production \& Operations, 23(4), 4-7.

Lee, M. L., Ng, W. S., and Tanaka, Y. 2013. "Stress-deformation and compressibility responses of bio-mediated residual soils.” Ecological Engineering, Elsevier B.V., 60, 142-149.

Li, M., Fu, Q. L., Zhang, Q., Achal, V., and Kawasaki, S. 2015. “Bio-grout based on microbially induced sand solidification by means of asparaginase activity." Scientific Reports, Nature Publishing Group, 5, 1-9.

Mitchell, A. C., and Ferris, F. G. 2005. “The coprecipitation of Sr into calcite precipitates induced by bacterial ureolysis in artificial groundwater: Temperature and kinetic dependence." Geochimica et Cosmochimica Acta, 69(17), 4199-4210.

Mitchell, A. C., and Ferris, F. G. 2006a. "Effect of strontium contaminants upon the size and solubility of calcite crystals precipitated by the bacterial hydrolysis of urea." Environmental Science and Technology, 40(3), 1008-1014.

Mitchell, A. C., and Ferris, F. G. 2006b. "The influence of bacillus pasteurii on the nucleation and growth of calcium carbonate.” Geomicrobiology Journal, 23(3-4), 213-226.

Nam, I., Chon, C., Jung, K., and Choi, S. 2014. "Calcite precipitation by ureolytic plant ( Canavalia ensiformis ) extracts as effective biomaterials." KSCE Journal of Civil Engineering, 1-6.

Nassar, M. K., Gurung, D., Bastani, M., Ginn, T. R., Shafei, B., Gomez, M. G., Graddy, C. M. R., 
Nelson, D. C., and DeJong, J. T. 2018. “Large-scale experiments in microbially induced calcite precipitation (MICP): Reactive transport model development and prediction." Water Resources Research RESEARCH, 3, 1127-1145.

Nemati, M., Greene, E. A., and Voordouw, G. 2005. "Permeability profile modification using bacterially formed calcium carbonate: Comparison with enzymic option.” Process Biochemistry, 40(2), 925-933.

Nemati, M., and Voordouw, G. 2003. "Modification of porous media permeability, using calcium carbonate produced enzymatically in situ." Enzyme and Microbial Technology, $33(5), 635-642$.

Neupane, D., Yasuhara, H., Kinoshita, N., and Ando, Y. 2015a. "Distribution of mineralized carbonate and its quantification method in enzyme mediated calcite precipitation technique." Soils and Foundations, Elsevier, 55(2), 447-457.

Neupane, D., Yasuhara, H., Kinoshita, N., and Putra, H. 2015b. "Distribution of grout material within 1-m sand column in insitu calcite precipitation technique.” Soils and Foundations, Elsevier, 55(6), 1512-1518.

Neupane, D., Yasuhara, H., Kinoshita, N., and Unno, T. 2013. “Applicability of enzymatic calcium carbonate precipitation as a soil-strengthening technique.” ASCE Journal of Geotechnical and Geoenvironmental Engineering, 139(December), 2201-2211.

Oliveira, P. J. V., Freitas, L. D., and Carmona, J. P. S. F. 2016. "Effect of soil type on the enzymatic calcium carbonate precipitation process used for soil improvement." Journal of Materials in Civil Engineering, 29(4), 1-7.

Park, S.-S., Choi, S.-G., and Nam, I.-H. 2014. "Effect of microbially induced calcite 
precipitation on strength of cemented sand." Journal of Materials in Civil Engineering, $26(8), 47-56$.

Park, S.-S., Nam, I.-H., and Choi, S.-G. 2011. "Natural soil-binder using natural bean and its use for soil cementation (콩을 이용한 지반의 천연고결제 및 이를 이용한 지반의 고결화 방법).” Kyungpook National University Industry-Academic Cooperation Foundation, South Korea 1011522950000 (in Korean), South Korea 1011522950000 (in Korean). Phillips, A. J., Cunningham, A. B., Gerlach, R., Hiebert, R., Hwang, C., Lomans, B. P., Westrich, J., Mantilla, C., Kirksey, J., Esposito, R., and Spangler, L. 2016. “Fracture sealing with microbially-induced calcium carbonate precipitation: A field study.” Environmental Science and Technology, 50(7), 4111-4117.

Putra, H., Yasuhara, H., and Kinoshita, N. 2017a. “Applicability of natural zeolite for NH-Forms removal in enzyme-mediated calcite precipitation technique.” Geosciences, (2).

Putra, H., Yasuhara, H., Kinoshita, N., and Hirata, A. 2017b. “Optimization of EnzymeMediated Calcite Precipitation as a Soil-Improvement Technique: The Effect of Aragonite and Gypsum on the Mechanical Properties of Treated Sand." Crystals, 7(2), 59.

Putra, H., Yasuhara, H., Kinoshita, N., Neupane, D., and Lu, C.-W. 2016. "Effect of Magnesium as Substitute Material in Enzyme-Mediated Calcite Precipitation for Soil-Improvement Technique." Frontiers in Bioengineering and Biotechnology, 4(May), 3-10.

Raymond, M., Gamage, M., Terefe, N. S., and Knoerzer, K. 2011. “Ultrasound in enzyme activation and inactivation." Ultrasound Technologies for Food and Bioprocessing, Food Engineering Series, H. Feng et al., ed., Springer Science+Business Media, LLC 2011, VIC, 
Australia, 369-404.

Simatupang, M., and Okamura, M. 2017. "Liquefaction resistance of sand remediated with carbonate precipitation at different degrees of saturation during curing." Soils and Foundations, The Japanese Geotechnical Society.

Sondi, I., and Salopek-Sondi, B. 2005. "Influence of the primary structure of enzymes on the formation of $\mathrm{CaCO} 3$ polymorphs: A comparison of plant (Canavalia ensiformis) and bacterial (Bacillus pasteurii) ureases.” Langmuir, 21(19), 8876-8882.

Soon, N. W., Lee, L. M., Khun, T. C., and Ling, H. S. 2013. "Improvements in engineering properties of soils through microbial-induced calcite precipitation.” KSCE Journal of Civil Engineering, 17(4), 718-728.

Soon, N. W., Lee, L. M., Khun, T. C., and Ling, H. S. 2014. "Factors affecting improvement in engineering properties of residual soil through microbial-induced calcite precipitation.” Journal of Geotechnical and Geoenvironmental Engineering, 04014006(11), 1-11.

Stocks-Fischer, S., Galinat, J. K., and Bang, S. S. 1999. "Microbiological precipitation of CaCO3." Soil Biology and Biochemistry, 31(11), 1563-1571.

Thevanayagam, S., Shenthan, T., Mohan, S., and Liang, J. 2002. "Undrained fragility of clean sands, silty sands, and sandy silts." Journal of Geotechnical and Geoenvironmental Engineering, 128(10), 849-859.

Tong, H., Ma, W., Wang, L., Wan, P., Hu, J., and Cao, L. 2004. “Control over the crystal phase, shape, size and aggregation of calcium carbonate via a L-aspartic acid inducing process.” Biomaterials, 25(17), 3923-3929.

van Paassen, L. A. 2009. "Biogrout: Ground improvement by microbially induced carbonate 
precipitation." Ph.D. dissertation, Delft University of Technology, Delft, Netherlands. van Paassen, L. A. 2011. "Bio-mediated ground improvement: from laboratory experiment to pilot applications." ASCE Geo-Frontiers, 4099-4108.

van Paassen, L. A., Ghose, R., van der Linden, T. J. M., van der Star, W. R. L., and van Loosdrecht, M. C. M. 2010a. "Quantifying biomediated ground improvement by ureolysis: large-scale biogrout experiment." Journal of Geotechnical and Geoenvironmental Engineering, 136(12), 1721-1728.

van Paassen, L. A., Harkes, M. P., Van Zwieten, G. A., Van Der Zon, W. H., Van Der Star, W. R. L., and Van Loosdrecht, M. C. M. 2009. "Scale up of BioGrout: A biological ground reinforcement method." Proceedings of the 17th International Conference on Soil Mechanics and Geotechnical Engineering: The Academia and Practice of Geotechnical Engineering, 3, 2328-2333.

van Paassen, L. A., Van Loosdrecht, M. C. M., Pieron, M., Mulder, A., Ngan-Tillard, D. J. M., and Van Der Linden, T. J. M. 2010b. "Strength and deformation of biologically cemented sandstone." Proc., Rock Engineering in Difficult Ground Conditions - Soft Rocks and Karst, I. Vrkljan, ed., CRC Press, Cavtat, Croatia, 405-410.

van der Star, W. R. L., van Wijngaarden-van Rossum, W. K., van Paassen, L. A., and van Baalen, L. R. 2011. "Stabilization of gravel deposits using microorganisms." Proceedings of the 15th European conference on Soil mechanics and Geotechnical engineering, A. Anagnostopoulos, ed., IOS Press, 85-90.

Whiffin, V. S. 2004. "Microbial CaCO3 precipitation for the production of biocement." Ph.D. 
dissertation, Murdoch University, Australia.

Whiffin, V. S., van Paassen, L. A., and Harkes, M. P. 2007. "Microbial carbonate precipitation as a soil improvement technique.” Geomicrobiology Journal, 24(February), 417-423.

Yamamuro, J. a., and Lade, P. V. 1998. "Steady-state concepts and static liquefaction of silty sands." Journal of Geotechnical and Geoenvironmental Engineering, 124(September), $868-877$.

Yasuhara, H., Hayashi, K., and Okamura, M. 2011. "Evolution in mechanical and hydraulic properties of calcite-cemented sand mediated mediated by biocatalyst." Geo-Frontiers 2011 C ASCE 2011, Dallas, Texas, 3984-3992.

Yasuhara, H., Neupane, D., Hayashi, K., and Okamura, M. 2012. "Experiments and predictions of physical properties of sand cemented by enzymatically-induced carbonate precipitation." Soils and Foundations, Elsevier, 52(3), 539-549. 


\section{List of figures:}

Fig. 1. Microscope images of culture: (a) before sonication; (b) after sonication

Fig. 2. Grain size distribution curve of tested soils

Fig. 3. Soil column circulating-percolation treatment (after Choi et al. 2016)

Fig. 4. Comparison between MICP and BEICP samples of sandy soil: unconfined compression strength versus $\mathrm{CaCO}_{3}$ precipitation at different number of treatment cycles

Fig. 5. Comparison between MICP and BEICP samples of sandy soil: Permeability versus $\mathrm{CaCO}_{3}$ precipitation at different number of treatment cycles

Fig. 6. Comparison of efficiency between MICP and BEICP methods (a) efficiency increase in UCS increasing (b) efficiency of permeability reduction

Fig. 7. SEM and schematic imagery of MICP-and BEICP-treated sandy soil samples (a) and (b) MICP at 8- and 16-cycle levels; (c) and (d) BEICP at 8- and 16-cycle levels

Fig. 8. XRD analysis of treated sand (a) MICP-treated 100-0 sand; (b) BEICP-treated 100-0 sand

Fig. 9. Original BEICP-treated 80-20 samples after eight treatment cycles: sample 1 was ovendried $\left(\approx 50^{\circ} \mathrm{C}, 48 \mathrm{~h}\right)$ before conducting UCS test; sample 2 was still in a wet condition after removal from its PVC mold

Fig. 10. Unconfined compression strength versus $\mathrm{CaCO}_{3}$ precipitation of BEICP samples at different number of treatment cycles

Fig. 11. Unconfined compression test, stress-strain curves of MICP- and BEICP-treated on sandy soil and silty-sand soil at 12 cycles of treatment

Fig. 12. Permeability versus $\mathrm{CaCO}_{3}$ precipitation of BEICP-treated samples at different number of treatment cycles 
Fig. 13. SEM magnifications of eight-cycle BEICP silty-sand: (a) 90-10 treatment with both direct sand-sand bridging plus co-enmeshed silt and calcite; (b) 80-20 enmeshed sand-siltcalcite matrix with lower direct sand-sand calcite bridging

Fig. 14. XRD analysis of silty sand soil (a) untreated loess fines (b) BEICP-treated 90-10 (c) BEICP-treated 80-20

Fig. 15. Higher SEM magnifications of varied calcite crystal sizes relative to different MICP and BEICP treatments: (a) MICP-treated sand at 8-cycle levels; (b) and (c) BEICP-treated sand at 8-and 16-cycle levels; (d) and (e) BEICP-treated silty sand at 8- and 16-cycle levels 


\section{List of tables:}

Table 1. Overview of Enzyme Induced Calcite Precipitation research publications

Table 2. Soil specimen properties

Table 3. Typical cyclic 'run-cool' sonication processing results for urease enzyme extraction

Table 4. Geotechnical laboratory results for MICP- and BEICP-treated soils versus untreated soils. 
Table 1. Overview of Enzyme Induced Calcite Precipitation research publications

\begin{tabular}{|c|c|c|c|c|}
\hline $\begin{array}{l}\text { Urease } \\
\text { source }\end{array}$ & $\begin{array}{r}\mathrm{C} \\
\text { hemical } \\
\text { supplier }\end{array}$ & $\begin{array}{c}\text { S } \\
\text { elf- } \\
\text { extracted }\end{array}$ & Application & References \\
\hline Jack beans & $\begin{array}{l}\mathrm{X} \\
\mathrm{X} \\
\mathrm{X} \\
\mathrm{X}\end{array}$ & $\mathrm{x}$ & $\begin{array}{l}\text { Permeability } \\
\text { reduction } \\
\text { Permeability } \\
\text { reduction } \\
\text { Dust suppression } \\
\text { Permeability reduction } \\
\text { \& strength increasing } \\
\text { Permeability } \\
\text { reduction } \\
\text { Permeability reduction } \\
\text { \& strength increasing } \\
\text { Permeability reduction; } \\
\text { strength increasing \& } \\
\text { dust suppression } \\
\text { Strength } \\
\text { increasing } \\
\text { Strength } \\
\text { increasing } \\
\text { Ureolytic } \\
\text { efficiency Strength } \\
\text { increasing } \\
\text { Crack healing }\end{array}$ & $\begin{array}{l}2005 \text { Nemati and Voordouw 2003; Nemati et al. } \\
\text { Larsen et al. 2008 } \\
\text { Bang et al. 2009 } \\
\text { Yasuhara et al. 2011, 2012 } \\
\text { Handley-Sidhu et al. 2013 } \\
\text { Neupane et al. 2013, 2015a; b } \\
\text { Hamdan et al. 2013, 2016; Hamdan and } \\
\text { Kavazanjian 2016; Kavazanjian and Hamdan } \\
\text { 2015; Kavazanjian et al. 2017 } \\
\text { Nam et al. 2014; Park et al. 2014 } \\
\text { Putra et al. 2016, 2017a; b } \\
\text { Jiang et al. 2016 } \\
\text { Oliveira et al. 2016 } \\
\text { Dakhane et al. 2018 }\end{array}$ \\
\hline $\begin{array}{l}\text { Water } \\
\text { melon seeds }\end{array}$ & & $\mathrm{x}$ & $\begin{array}{l}\text { Strength } \\
\text { increasing }\end{array}$ & Dilrukshi et al. 2016 \\
\hline $\begin{array}{l}\text { Sword } \\
\text { beans }\end{array}$ & $\mathrm{X}$ & & $\begin{array}{l}\text { Strength } \\
\text { increasing }\end{array}$ & Simatupang and Okamura 2017 \\
\hline
\end{tabular}


1.

Table 2. Soil specimen properties

\begin{tabular}{ccccrrrrrc}
\hline Material & USCS & $\begin{array}{c}\text { Packing } \\
\text { method }\end{array}$ & $\mathrm{e}$ & $\begin{array}{r}\mathrm{D}_{10} \\
(\mathrm{~mm})\end{array}$ & $\begin{array}{c}\mathrm{D}_{50} \\
(\mathrm{~mm})\end{array}$ & $\begin{array}{c}\mathrm{FC} \\
(\%)\end{array}$ & $\begin{array}{c}\mathrm{LL} \\
(\%)\end{array}$ & $\begin{array}{c}\mathrm{PL} \\
(\%)\end{array}$ & $\begin{array}{c}\mathrm{CaCO}_{3} \\
(\%)\end{array}$ \\
\hline $100-0$ & SP & Wet tamping & \multirow{2}{*}{$0.58-$} & 0.58 & 0.72 & 0 & $\mathrm{NP}$ & $\mathrm{NP}$ & 0 \\
$90-10$ & SP-SM & Wet tamping & 0.61 & 0.06 & 0.7 & 10 & 34.5 & 27.3 & 0.8 \\
$80-20$ & SM & Wet tamping & & 0.028 & 0.67 & 20 & 34.5 & 27.3 & 1.6 \\
\hline
\end{tabular}

Note: $\mathrm{NP}=$ Nonplastic 
1.

Table 3. Typical cyclic 'run-cool' sonication processing results for urease enzyme extraction

\begin{tabular}{|c|c|c|c|}
\hline \multicolumn{2}{|c|}{ Test conditions and measurements } & Control (culture) & Cyclic run-cool sonication \\
\hline \multicolumn{2}{|c|}{ Sonication total 'run' times (min) } & 0 & 60 \\
\hline \multicolumn{2}{|c|}{ Optical density (600nm) } & 1.25 & 0.34 \\
\hline \multicolumn{2}{|r|}{$\mathrm{pH}$} & 8 & 7.92 \\
\hline \multicolumn{2}{|c|}{ Temperature $\left(\mathrm{C}^{0}\right)$} & 30 & 34 \\
\hline \multicolumn{2}{|c|}{ Volume reduction $(\%)$} & 0 & 20 \\
\hline \multirow{2}{*}{$\begin{array}{c}\text { Urease } \\
\text { activity } \\
(\mathrm{mM} / \mathrm{min})\end{array}$} & Measured & \multirow[b]{2}{*}{12.1} & 25.4 \\
\hline & $\begin{array}{c}\text { Activity ratio } \\
\text { (measured : control) }\end{array}$ & & 2.1 \\
\hline
\end{tabular}


1.

Table 4. Geotechnical laboratory results for MICP- and BEICP-treated soils versus untreated soils

\begin{tabular}{|c|c|c|c|c|c|c|c|c|c|c|c|}
\hline \multirow{2}{*}{ Sample ID } & \multirow{2}{*}{$\begin{array}{l}\mathrm{FC} \\
(\%)\end{array}$} & \multirow{2}{*}{$\begin{array}{c}\text { Cycle } \\
\text { \#'s }\end{array}$} & \multirow{2}{*}{$\begin{array}{c}\text { No. } \\
\text { samples }\end{array}$} & \multicolumn{2}{|c|}{$\mathrm{UCS}(\mathrm{kPa})$} & \multicolumn{2}{|c|}{$\mathrm{CaCO}_{3}(\%)$} & \multicolumn{3}{|c|}{ Permeability $(\mathrm{cm} / \mathrm{s})$} & \multirow{2}{*}{$\begin{array}{c}\text { ICP } \\
\text { options }\end{array}$} \\
\hline & & & & $\mathrm{AVG}^{\mathrm{a}}$ & $\mathrm{STD}^{\mathrm{b}}$ & $\mathrm{AVG}^{\mathrm{a}}$ & $\mathrm{STD}^{\mathrm{b}}$ & $\mathrm{AVG}^{\mathrm{a}}$ & $\mathrm{STD}^{\mathrm{b}}$ & Relative error ${ }^{\mathrm{c}}$ & \\
\hline B100-0-8 & 0 & \multirow{3}{*}{8} & 3 & 600 & 119 & 2.23 & 0.45 & $3.60 \times 10^{-02}$ & $3.48 \times 10^{-02}$ & $4.20 \times 10^{-01}$ & \multirow{3}{*}{$\mathrm{B}$} \\
\hline B90-10-8 & 10 & & 3 & 394 & 79 & 4.10 & 0.56 & $1.28 \times 10^{-02}$ & $9.12 \times 10^{-03}$ & $3.10 \times 10^{-01}$ & \\
\hline B80-20-8 & 20 & & 3 & 231 & 50 & 5.47 & 0.93 & $3.10 \times 10^{-03}$ & $1.57 \times 10^{-03}$ & $2.20 \times 10^{-01}$ & \\
\hline B100-0-12 & 0 & \multirow{3}{*}{12} & 3 & 1340 & 105 & 5.23 & 0.91 & $2.34 \times 10^{-02}$ & $2.41 \times 10^{-02}$ & $4.47 \times 10^{-01}$ & \multirow{6}{*}{$\begin{array}{c}\mathrm{E} \\
\mathrm{I} \\
\mathrm{C} \\
\mathrm{P}\end{array}$} \\
\hline B90-10-12 & 10 & & 3 & 972 & 74 & 11.74 & 1.14 & $3.53 \times 10^{-03}$ & $2.20 \times 10^{-03}$ & $2.70 \times 10^{-01}$ & \\
\hline B80-20-12 & 20 & & 3 & 711 & 109 & 12.87 & 1.78 & $2.52 \times 10^{-03}$ & $2.62 \times 10^{-03}$ & $4.51 \times 10^{-01}$ & \\
\hline B100-0-16 & 0 & \multirow{3}{*}{16} & 3 & 1691 & 634 & 7.12 & 1.51 & $6.52 \times 10^{-03}$ & $8.14 \times 10^{-04}$ & $5.42 \times 10^{-02}$ & \\
\hline B90-10-16 & 10 & & 3 & 1118 & 45 & 12.59 & 1.52 & $9.62 \times 10^{-04}$ & $9.92 \times 10^{-04}$ & $4.47 \times 10^{-01}$ & \\
\hline B80-20-16 & 20 & & 3 & 842 & 187 & 13.15 & 3.08 & $1.87 \times 10^{-04}$ & $1.52 \times 10^{-04}$ & $3.53 \times 10^{-01}$ & \\
\hline M100-0-8 & 0 & 8 & 3 & 742 & 89 & 5.69 & 0.53 & $1.11 \times 10^{-02}$ & $6.40 \times 10^{-03}$ & $2.50 \times 10^{-01}$ & \multirow{2}{*}{ M } \\
\hline M100-0-12 & 0 & \multirow{3}{*}{12} & 3 & 1662 & 191 & 11.04 & 1.75 & $2.40 \times 10^{-03}$ & $1.59 \times 10^{-03}$ & $2.88 \times 10^{-01}$ & \\
\hline M90-10-12 & 10 & & 1 & & & & & Failure & & & \multirow{3}{*}{$\begin{array}{l}\mathrm{C} \\
\mathrm{P}\end{array}$} \\
\hline M80-20-12 & 20 & & 1 & & & & & Failure & & & \\
\hline M100-0-16 & 0 & 16 & 3 & 1960 & 284 & 13.48 & 2.02 & $4.47 \times 10^{-04}$ & $3.96 \times 10^{-04}$ & $3.62 \times 10^{-01}$ & \\
\hline U100 & 0 & \multirow{3}{*}{0} & 1 & \multirow{3}{*}{\multicolumn{2}{|c|}{$\mathrm{N} / \mathrm{A}^{\mathrm{d}}$}} & \multicolumn{2}{|c|}{0} & \multicolumn{3}{|c|}{$1.01 \times 10^{-01}$} & \multirow{3}{*}{ Un-treated } \\
\hline U90 & 10 & & 1 & & & & & & $6.41 \times 10^{-02}$ & & \\
\hline U80 & 20 & & 1 & & & & & & $2.56 \times 10^{-02}$ & & \\
\hline
\end{tabular}

Note: ${ }^{\mathrm{a}}$ average; ${ }^{\mathrm{b}}$ standard deviation; ${ }^{\mathrm{c}}$ relative error necessary for log-based plots (Baird 1994); ${ }^{\mathrm{d}}$ not analyzed 

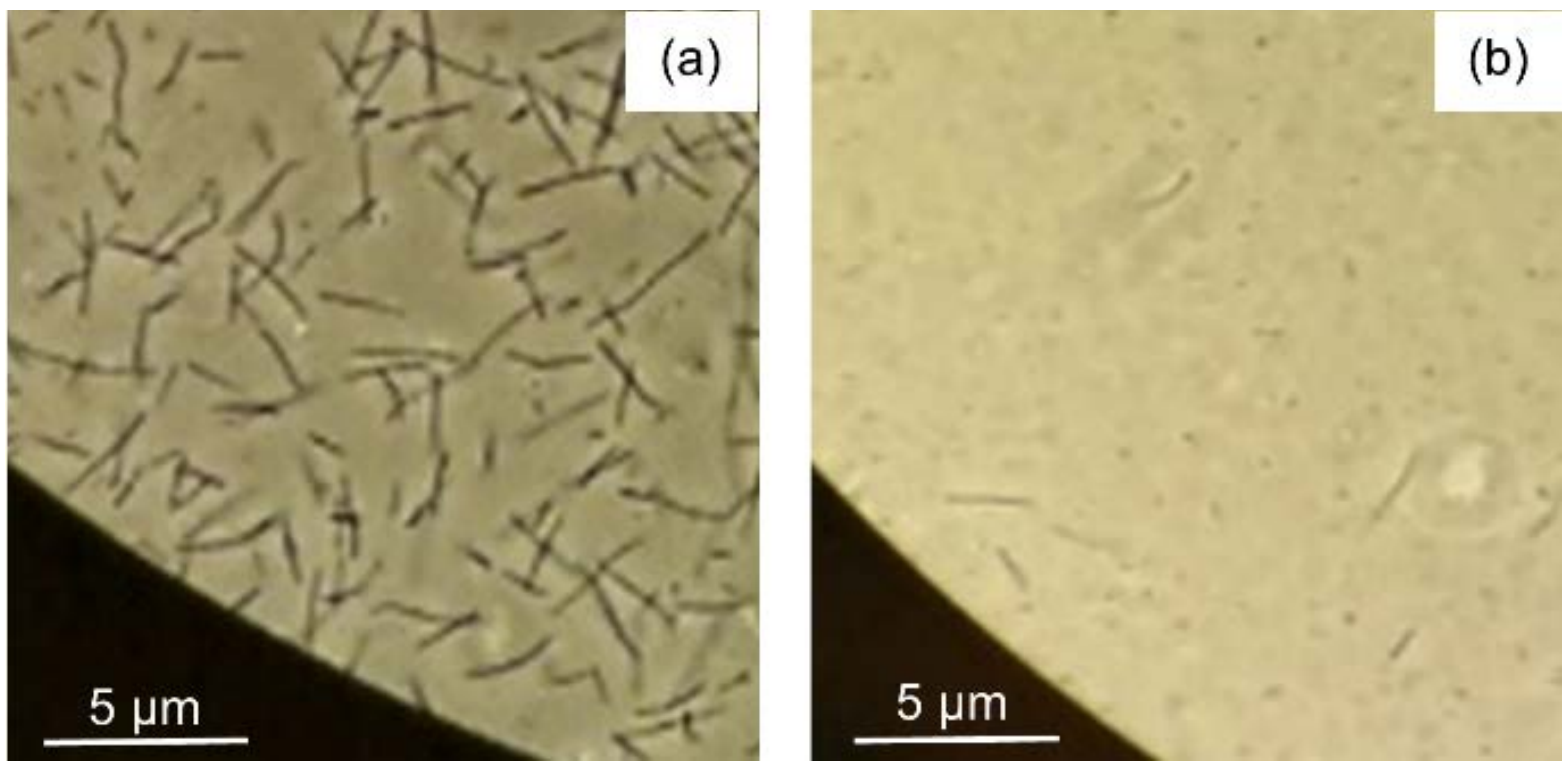

Fig. 1. Microscope images of culture: (a) before sonication (showing intact cells); (b) after sonication (showing cell lysis) 


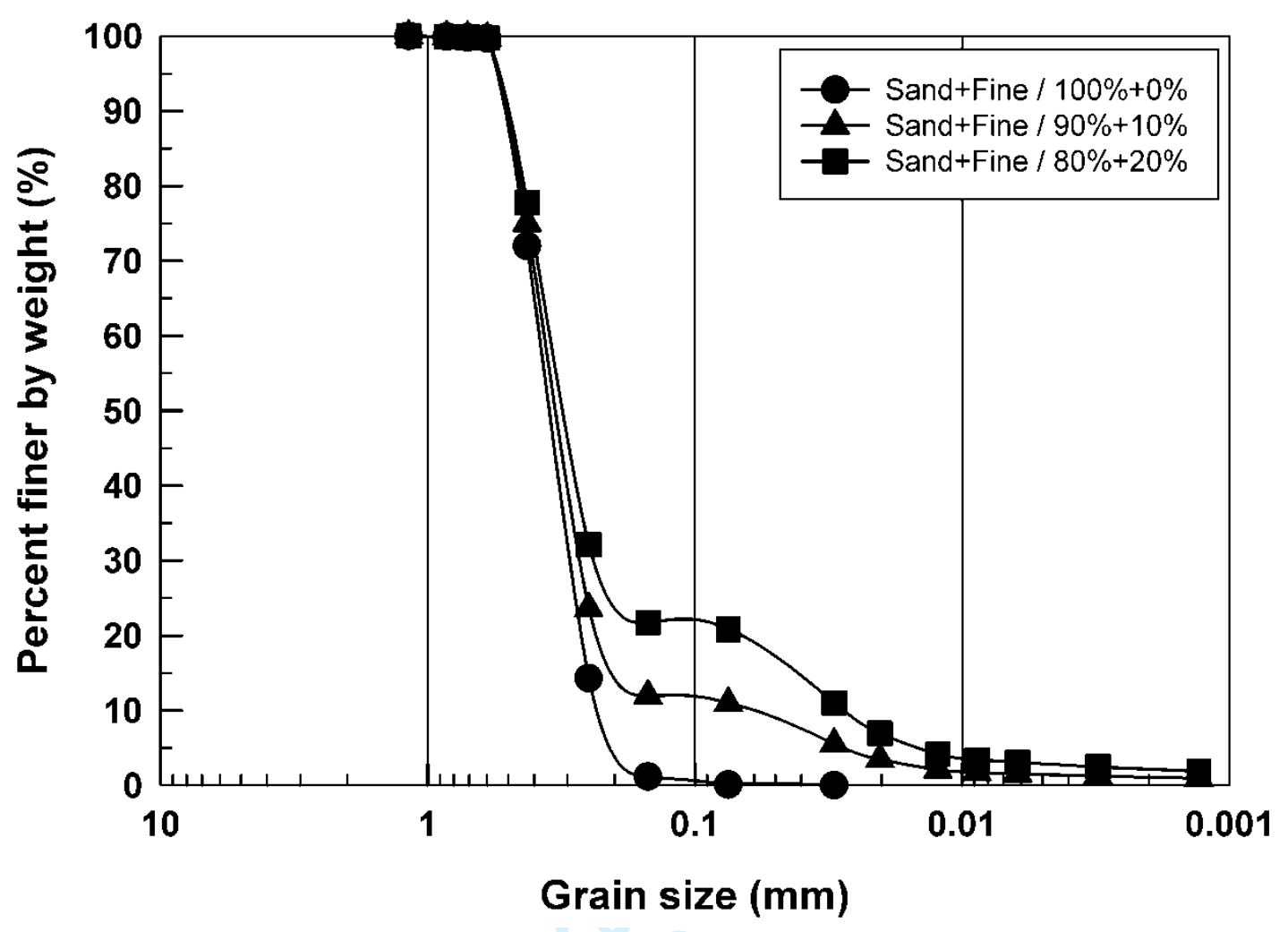

Fig. 2. Grain size distribution curve of tested soils 


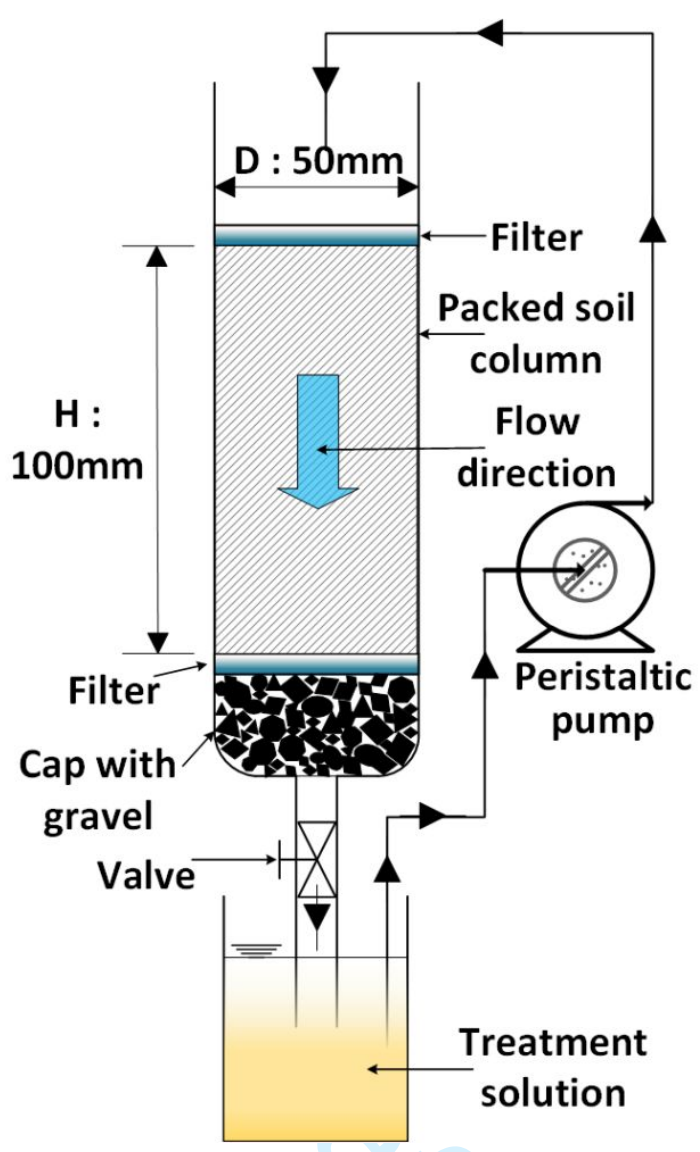

Fig. 3. Soil column circulating-percolation treatment (after Choi et al. 2016) 


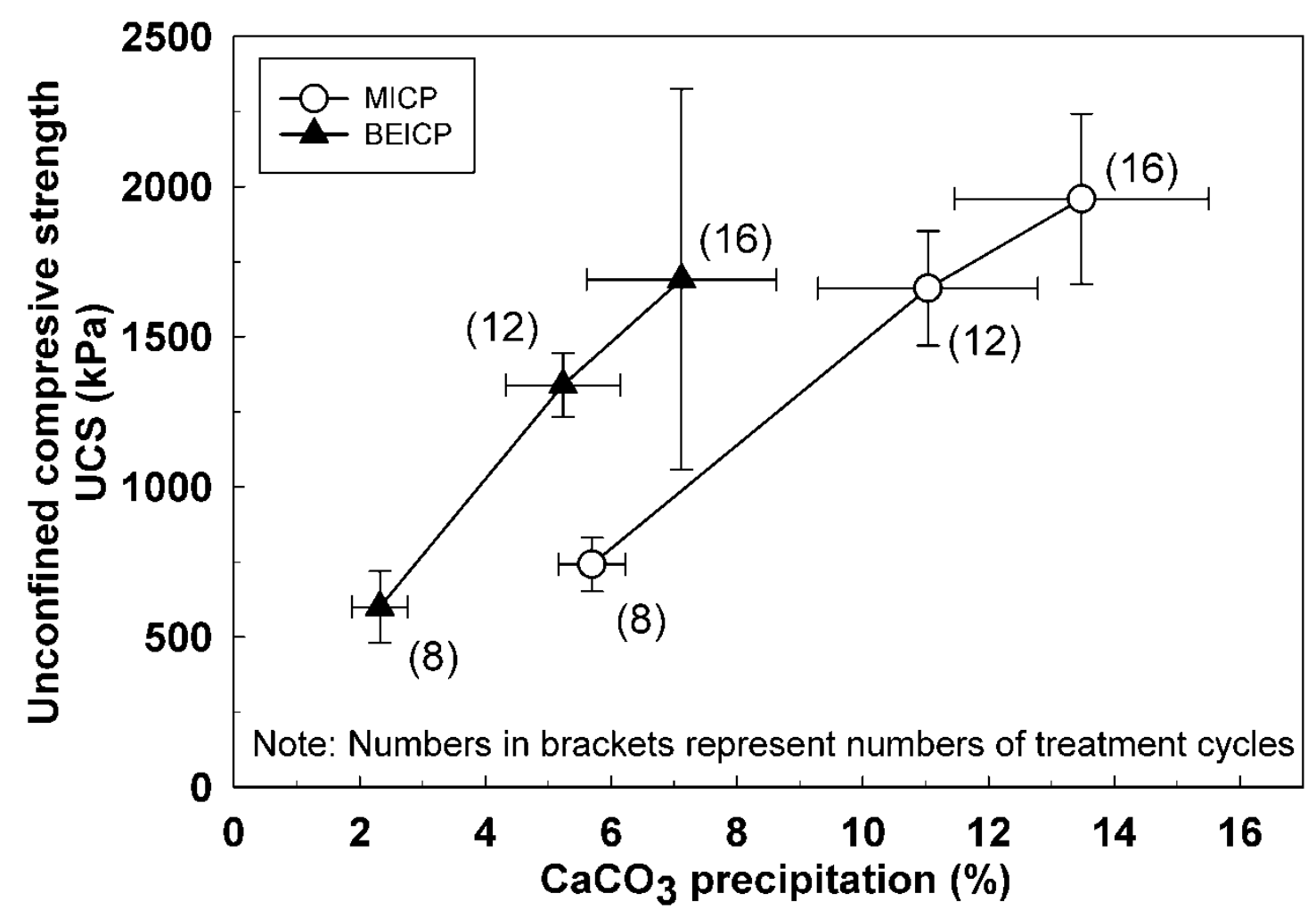

Fig. 4. Comparison between MICP and BEICP samples of sandy soil: unconfined compression strength versus $\mathrm{CaCO}_{3}$ precipitation at different number of treatment cycles 


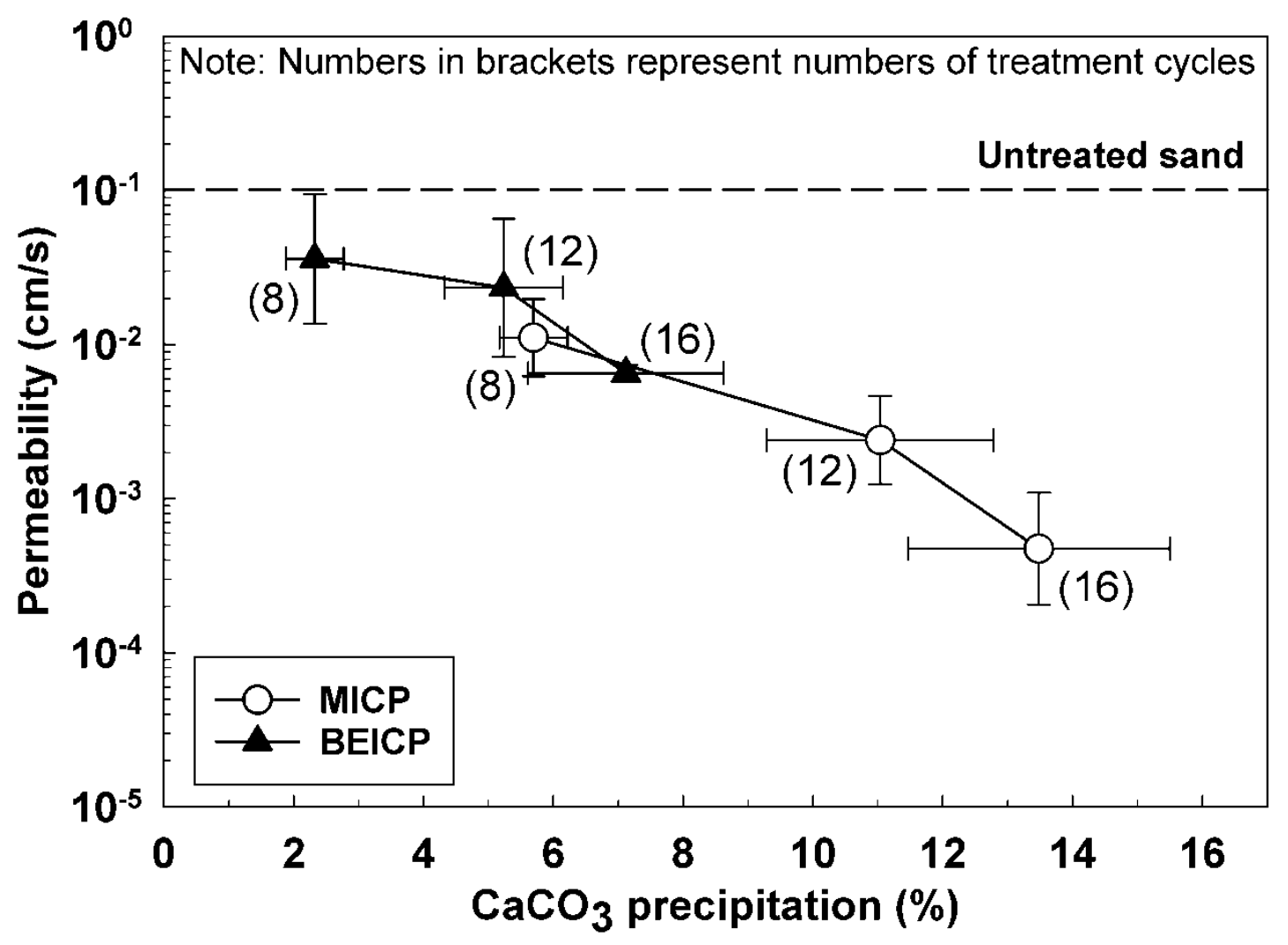

Fig. 5. Comparison between MICP and BEICP samples of sandy soil: Permeability versus $\mathrm{CaCO}_{3}$ precipitation at different number of treatment cycles 

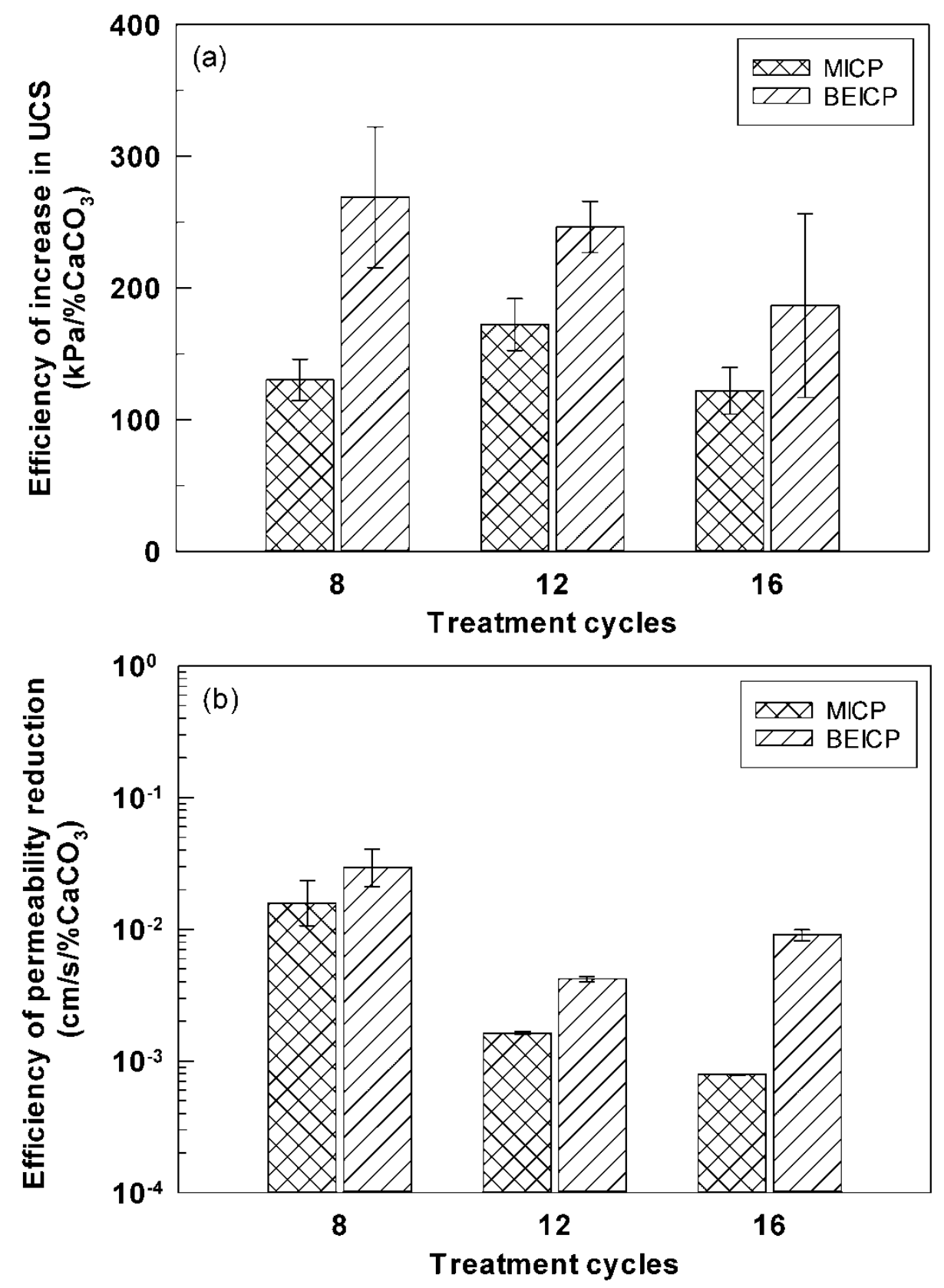

Fig. 6. Comparison of efficiency between MICP and BEICP methods: (a) efficiency of increase in UCS; (b) efficiency of permeability reduction 

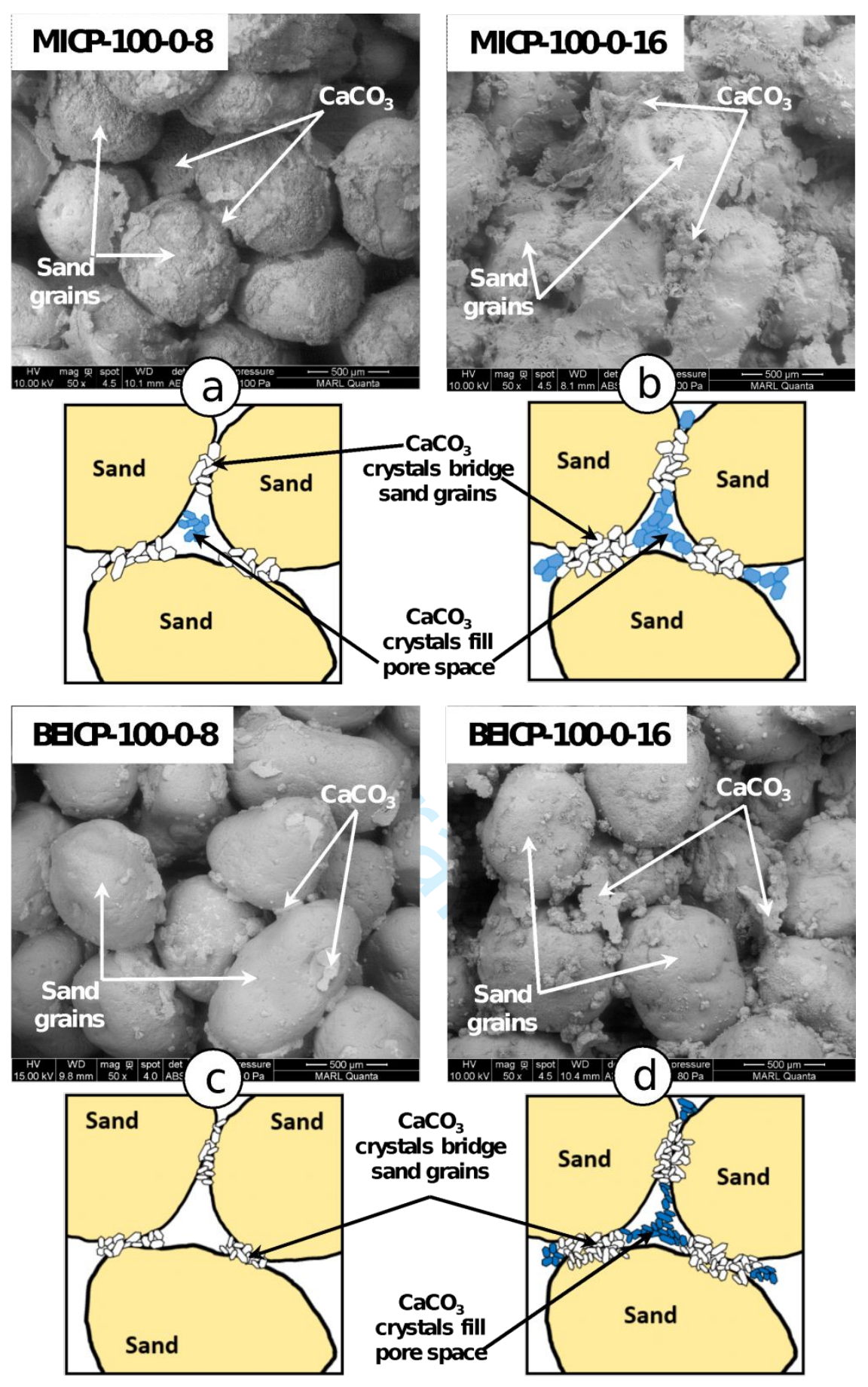

Fig. 7. SEM and schematic imagery of MICP- and BEICP-treated sandy soil samples (a) and (b) MICP at 8- and 16-cycle levels; (c) and (d) BEICP at 8- and 16-cycle levels 

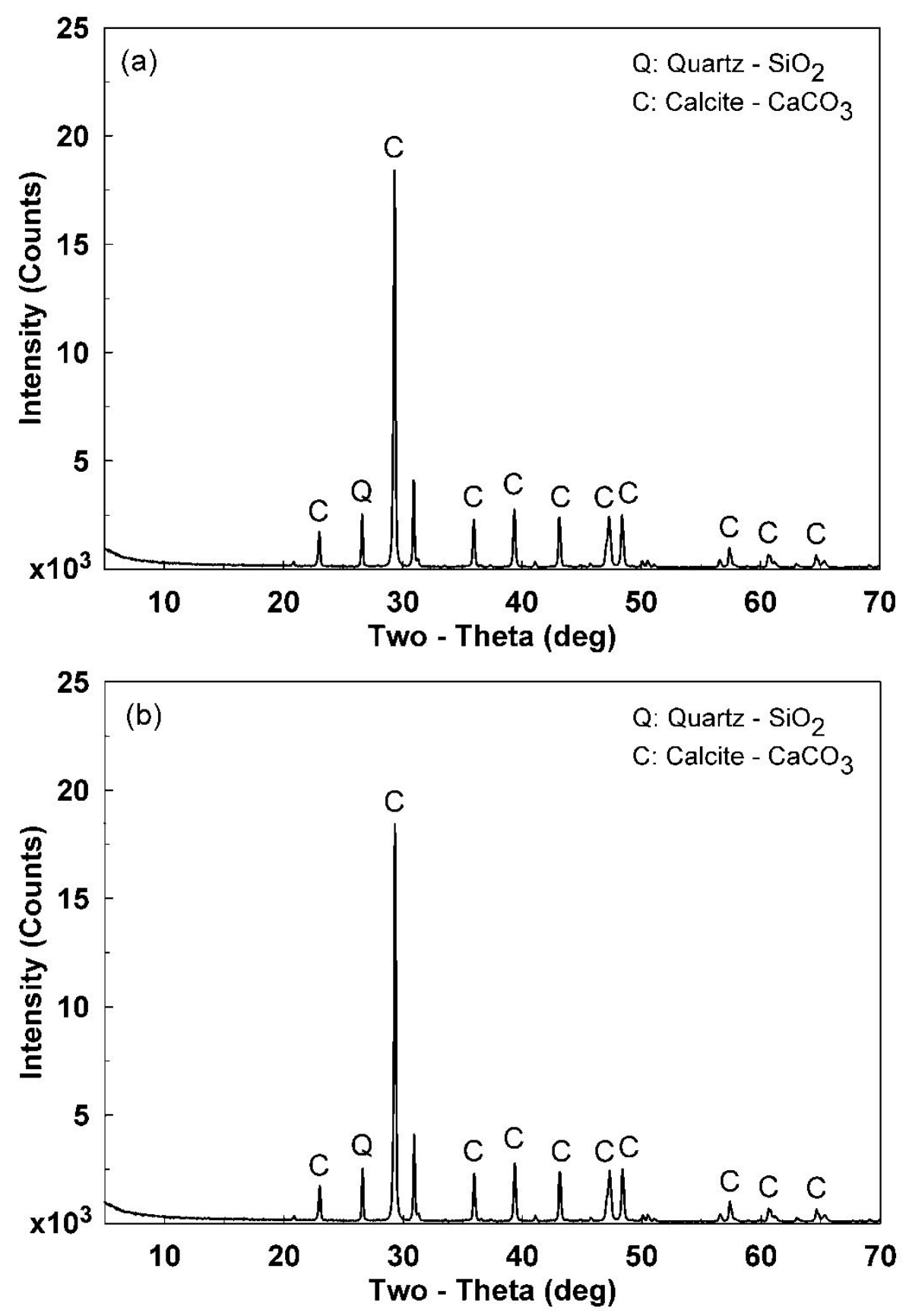

Fig. 8. XRD analysis of treated sand: (a) MICP-treated 100-0 sand and; (b) BEICP-treated 100-0 sand 


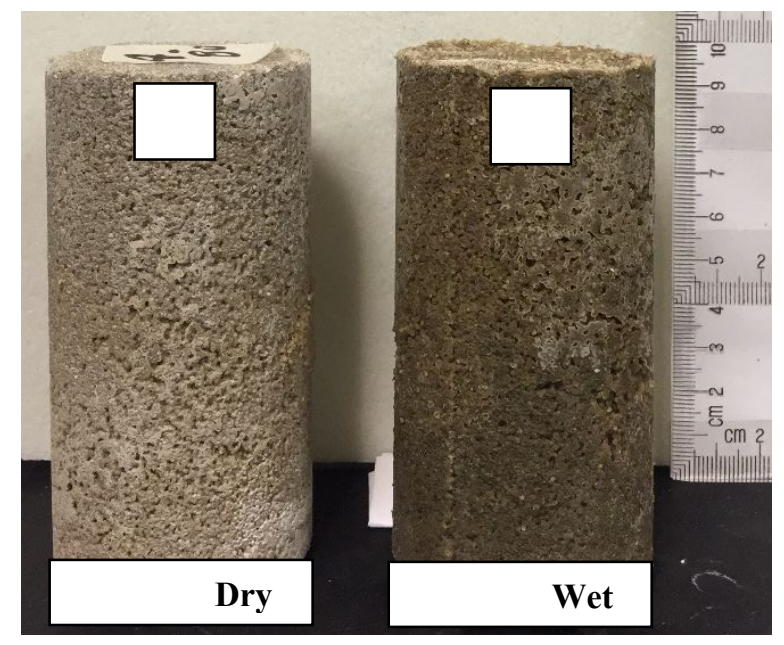

Fig. 9. Original BEICP-treated 80-20 samples after eight treatment cycles: sample 1 was ovendried $\left(\approx 50^{\circ} \mathrm{C}, 48 \mathrm{~h}\right)$ before conducting UCS test; sample 2 was still in a wet condition after removal from its PVC mold. 


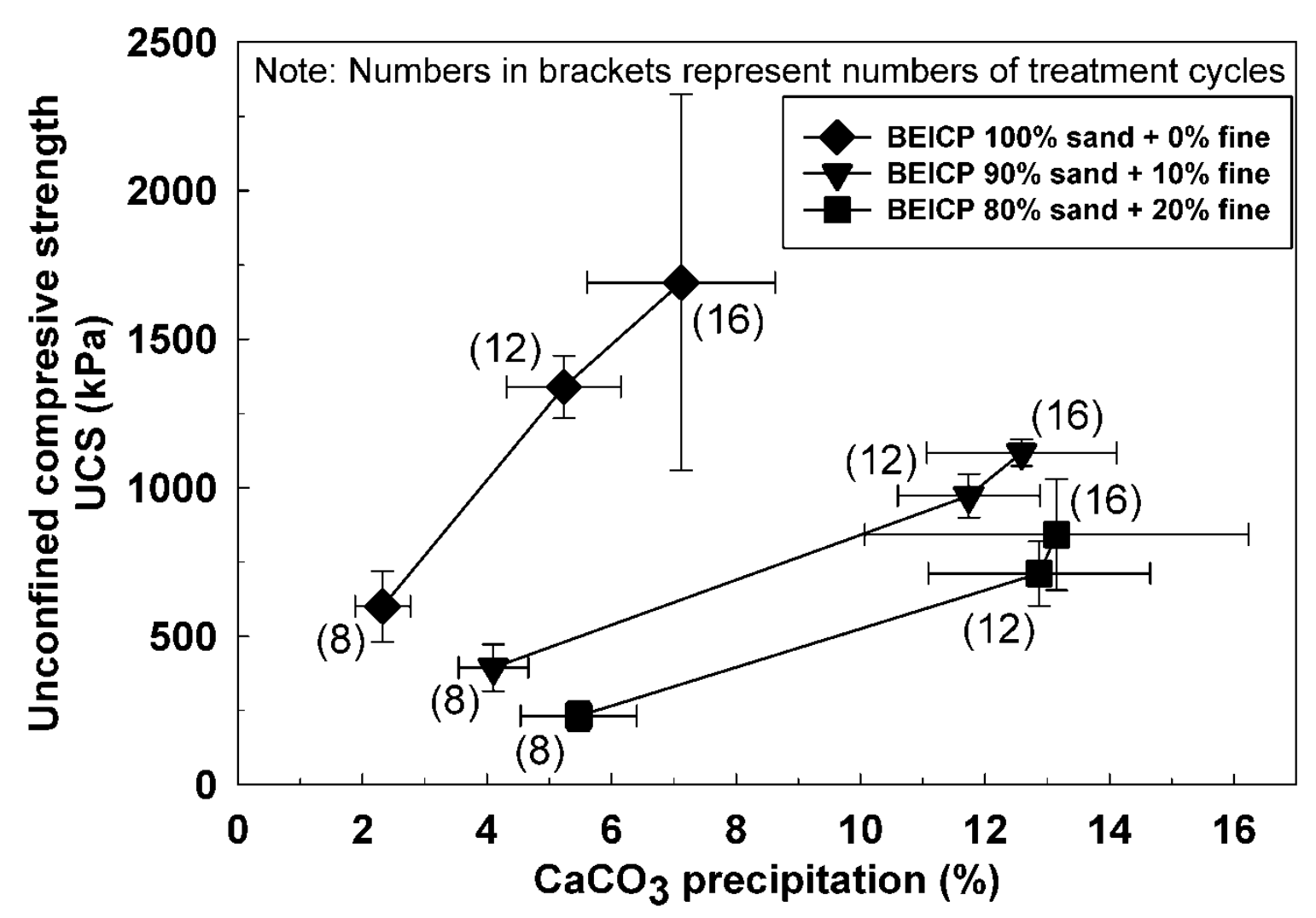

Fig. 10. Unconfined compression strength versus $\mathrm{CaCO}_{3}$ precipitation of BEICP samples at different number of treatment cycles 


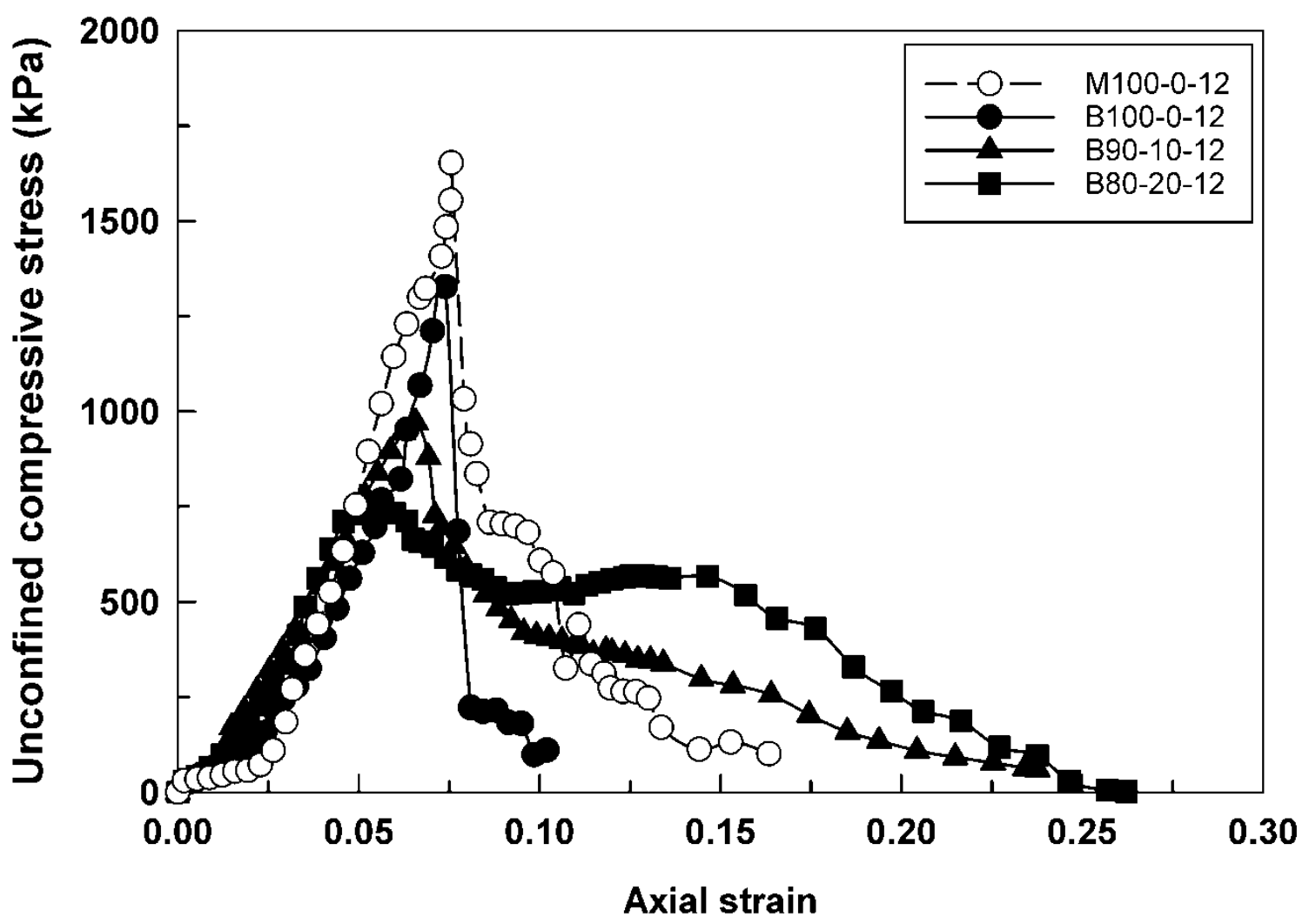

Fig. 11. Unconfined compression test, stress-strain curves of MICP- and BEICPtreated on sandy soil and silty-sand soil at 12 cycles of treatment 


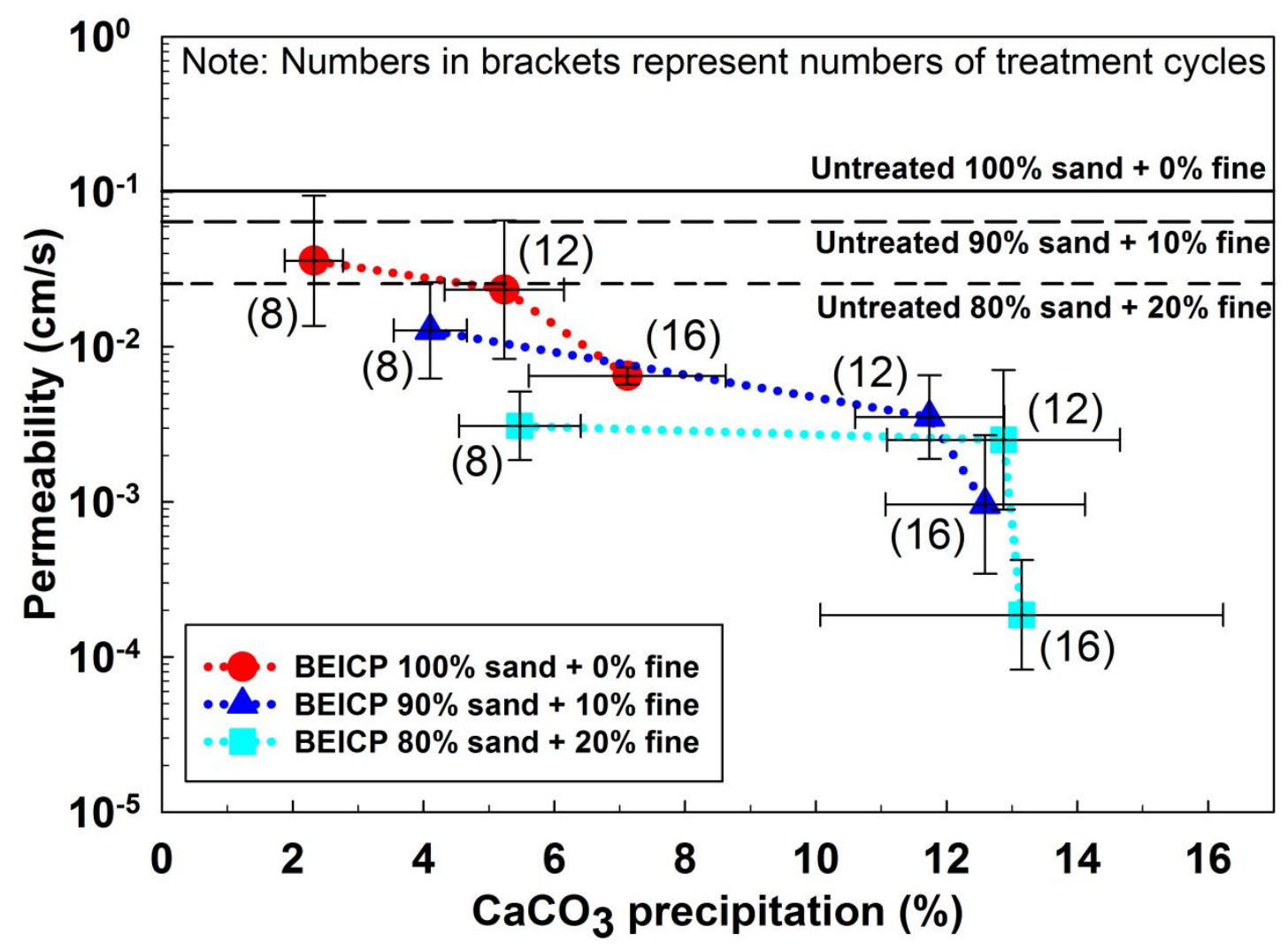

Fig. 12. Permeability versus $\mathrm{CaCO}_{3}$ precipitation of BEICP-treated samples at different number of treatment cycles 

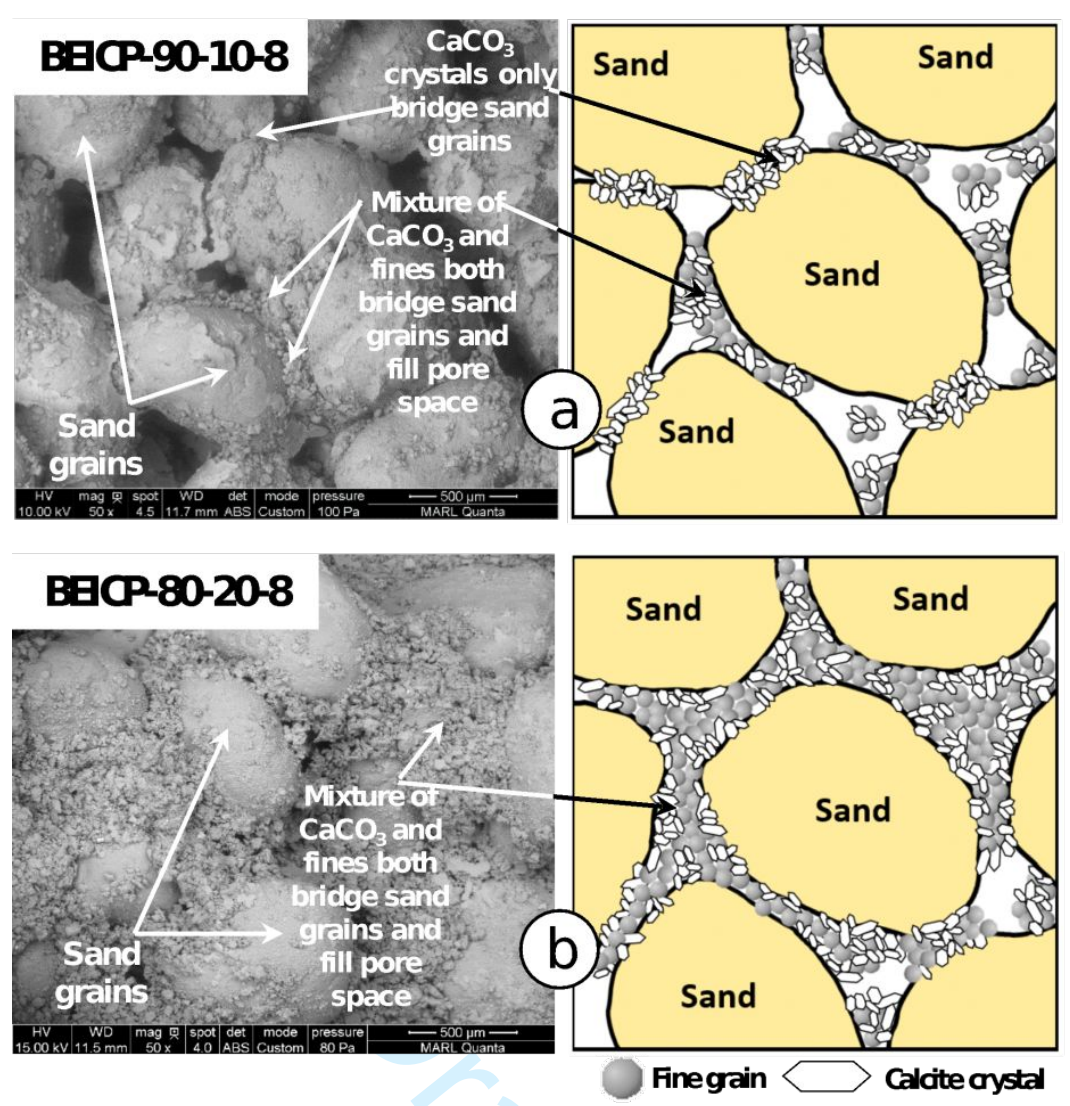

Fig. 13. SEM magnifications of eight-cycle BEICP silty-sand: (a) 90-10 treatment with both direct sand-sand bridging plus co-enmeshed silt and calcite; (b) 80-20 enmeshed sand-silt-calcite matrix with lower direct sand-sand calcite bridging 

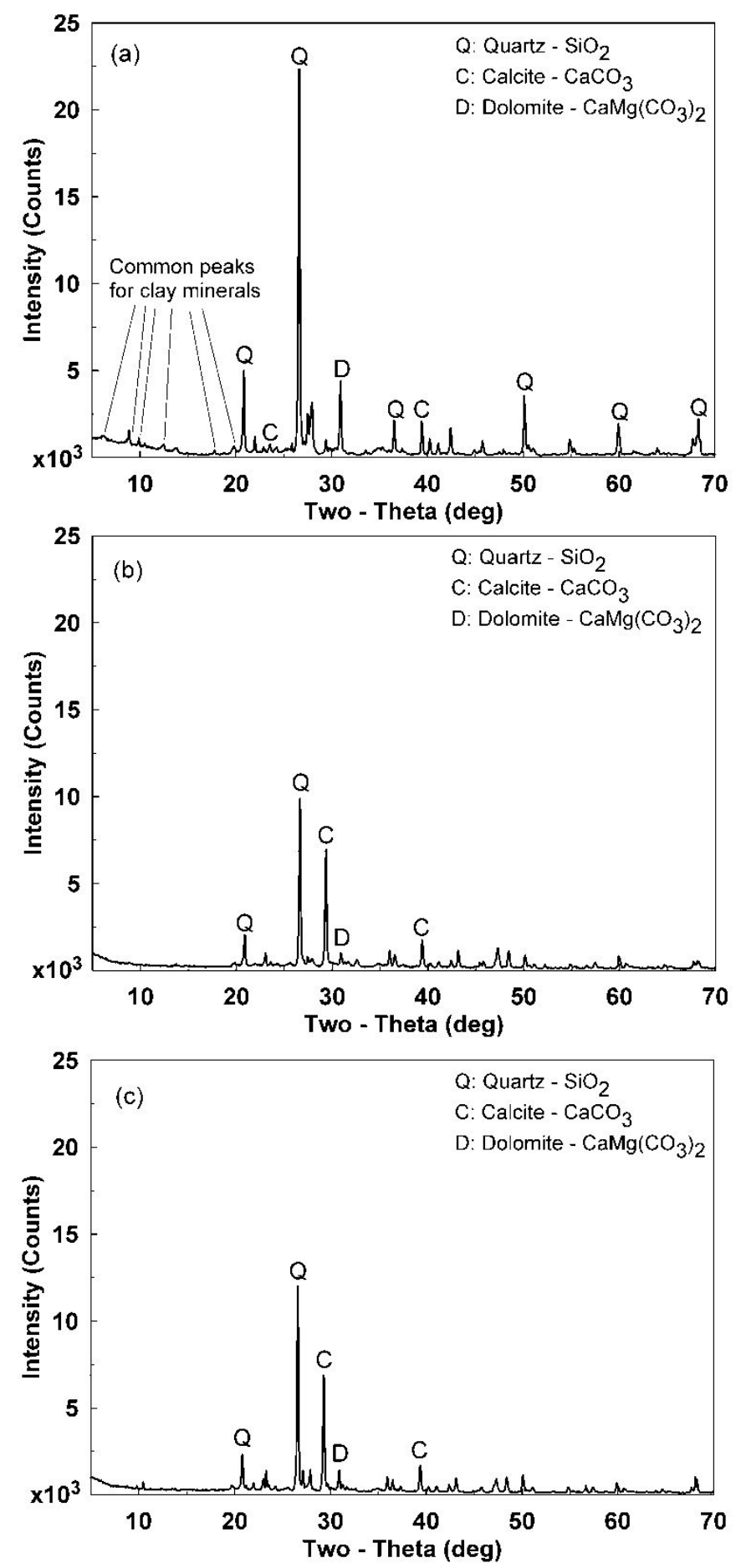

Fig. 14. XRD analysis of silty sand soil: (a) untreated loess fines; (b) BEICP-treated 90-10; (c)

BEICP-treated 80-20 

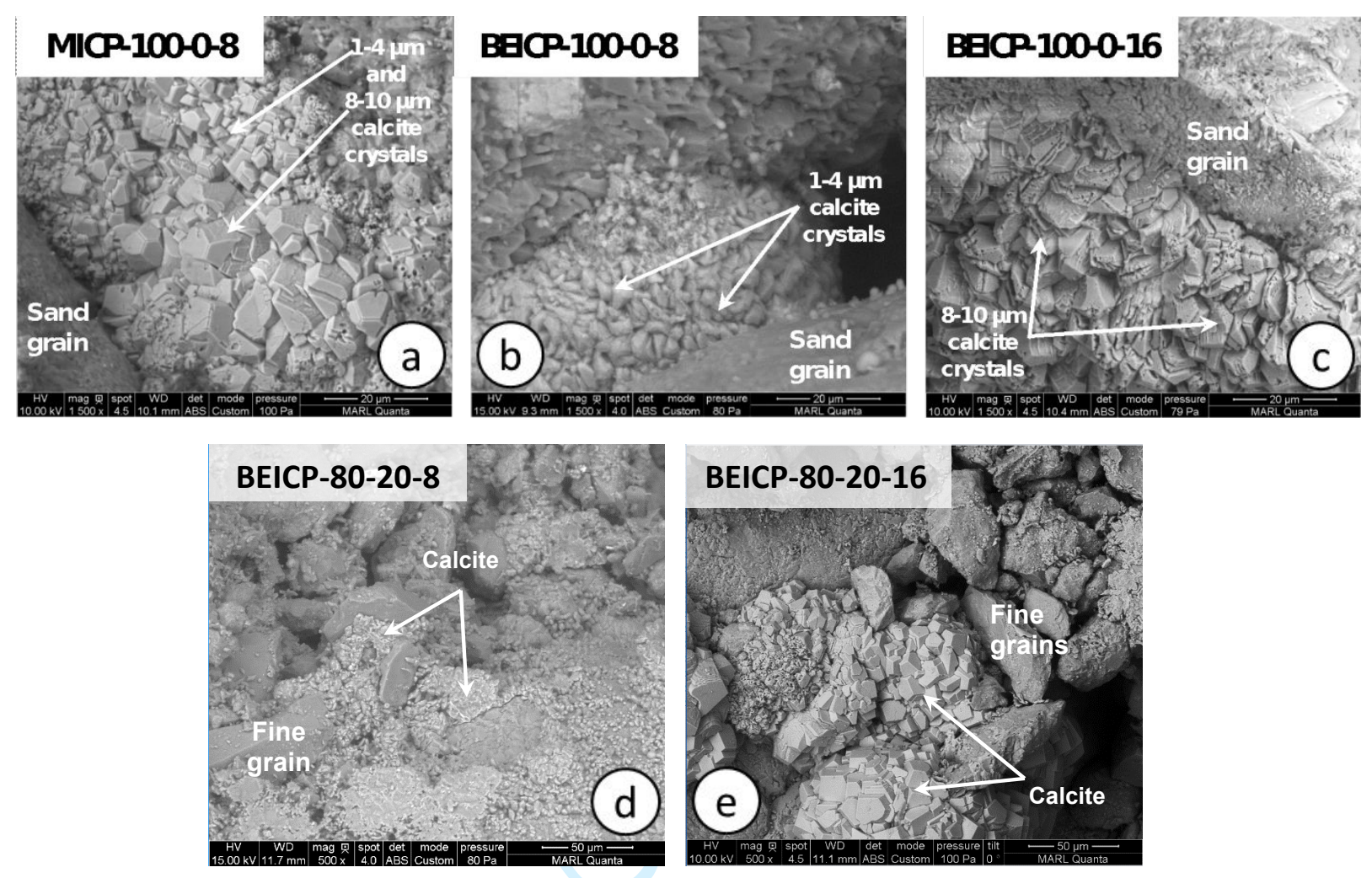

1. $\quad$ Fig. 15. Higher SEM magnifications of varied calcite crystal sizes relative to different MICP and BEICP treatments: (a) MICP-treated sand at 8-cycle levels; (b) and (c) BEICP-treated sand at 8- and 16cycle levels; (d) and (e) BEICP-treated silty sand at 8- and 16cycle levels 